Understanding consumer intention to participate in online travel community and effects on consumer intention to purchase travel online and WOM: an integration of innovation diffusion theory and TAM with trust

El-Masry, AA

http://hdl.handle.net/10026.1/4696

10.1016/j.chb.2016.02.038

Computers in Human Behavior

Elsevier

All content in PEARL is protected by copyright law. Author manuscripts are made available in accordance with publisher policies. Please cite only the published version using the details provided on the item record or document. In the absence of an open licence (e.g. Creative Commons), permissions for further reuse of content should be sought from the publisher or author. 
Full length article

\title{
Understanding consumer intention to participate in online travel community and effects on consumer intention to purchase travel online and WOM: An integration of innovation diffusion theory and TAM with trust
}

\author{
Gomaa Agag a, b, *, Ahmed A. El-Masry a, c \\ ${ }^{a}$ University of Plymouth Business School, Drake Circus, Plymouth, Devon PL4 8AA, UK \\ b Sadat City University, Egypt \\ ${ }^{\mathrm{c}}$ Umm Al-Qura University College of Business, Saudi Arabia
}

\section{A R T I C L E I N F O}

\section{Article history:}

Received 12 June 2015

Received in revised form

2 February 2016

Accepted 9 February 2016

Available online xxx

\section{Keywords:}

Intention to participate

Online travel communities

Innovation diffusion theory

TAM

Trust

WOM

\begin{abstract}
A B S T R A C T
The growing presence of online travel communities is leading to great developments in the travel industry. Grounded in the innovation diffusion theory (IDT) and the technology acceptance model (TAM), this paper seek to develop and empirically test a comprehensive framework to examine the antecedents of customers' intention to participate in online travel community. Using SEM to analyse the data collected from a sample of 495 members, the results indicate that innovation diffusion theory and TAM with trust provide an appropriate model for explaining consumers' intention to participate; this intention in turn has a positive influence on intention to purchase and positive WOM. Furthermore, religiosity plays an important role in understanding consumers' behavioural intention. The results offer important implications for online service provider and are likely to stimulate further research in the area of online travel community.
\end{abstract}

() 2016 Elsevier Ltd. All rights reserved.

\section{Introduction}

Information Communication Technologies, especially the Internet, is leading to great developments in the tourism industry (Buhalis \& Law, 2008). Internet has come as a new way of communication and selling for travel companies (Law \& Wong, 2003; Llach, Mariomon, \& Alonso-Almeida, 2013). Radical changes in social interactions have been initiated due to the emergence of Information Communication Technologies, which in return provide important implications for the online communities' formation (Wasko \& Faraj, 2005; Wiertz \& Ruyter, 2007).

The benefits of online travel communities extend to both for travel searchers and tourism marketing firms. For travellers, online travel community enables traveller to discover what other persons think about potential facilities such as hotels and restaurants,

\footnotetext{
* Corresponding author. University of Plymouth Business School, Drake Circus, Plymouth, Devon PL4 8AA, UK.

E-mail addresses: gomaa.agag@plymouth.ac.uk (G. Agag), ahmed.el-masry@ plymouth.ac.uk (A.A. El-Masry).
}

traveller can access information easily which enable travellers to extract more value from the travel companies (Qu \& Lee, 2011). For tourism marketing firms, online travel communities facilitate deep and constant relationships with consumers (Bagozzi \& Dholakia, 2002), reduce the costs of consumer service (Prahalad, 2000; Wiertz \& Ruyter, 2007). Furthermore, online travel communities reflect the progressively popular "consumer empowerment" movement (Tsai \& Pai, 2014).

Yet despite the substantial implications and importance of online communities for tourism firms (Qu \& Lee, 2011; Wang, Yu, \& Fesenmaier, 2002), little attention has been given to the antecedents and consequences of the intentions of customers to participate in these online communities (Casaló, Flavián, \& Guinaliu, 2010; Qu \& Lee, 2011; Tsai \& Pai, 2014). Prior studies have mostly concentrated on the drivers of consumer involvement and contributions to the online travel communities, because energetic participation is an important element in order to guarantee the survival of the online community. In fact, if none participated in the community, it would cease to exist (Wasko \& Faraj, 2005). Nevertheless, a scant of consensus continues to exist regarding the major determinants of consumer intention to participate. For example, Casaló et al. (2010) 
pointed out that consumer participation in online travel communities is affected by perceived ease of use and perceived usefulness, but it also seems to be affected by hedonic and norms benefits (Wang \& Fesenmaier, 2004). Consumer participation and building prosperous online travel communities are frequently cited central challenges for any online travel community provider. Therefore, examining and understanding determinants of consumer intention participation has become a key question in online travel community studies. Consequently, this study proposes an integrated model that identifies key factors that affect the intention of consumer to participate in online travel community. Moreover, this study examines the effect of consumer intention to participate on consumer intention to purchase travel online and positive word of mouth. Understanding these behavioural intentions may benefit this online travel community.

The current study aims to contribute the following to the literature of tourism and relationship marketing: 1) identify the most crucial determinants that effect consumer intention to participate in online travel communities; 2) by integrating two wellrecognised technology adaption theories: the innovation diffusion theory and the Technology Acceptance Model (TAM), we help to understand the intention of consumers to participate in online travel community; 3) we examine the influence of consumers' intentions to participate on both the intention to purchase travel online and positive word of mouth (WOM). 4) We also examine the moderating role of religiosity on the association between consumer intention to participate, attitude, trust, and intention to purchase travel online. The findings will help tourism companies' managers and other tourism institutions to evolve strategies that enhance the intention of consumer to participate as well as evolving strategies that improve consumer intentions to purchase travel online and consumer intentions to recommend the online travel community.

Our study is organized as follow; the next section represents literature pertaining to the study variables and theories as well as the hypotheses development. Then we demonstrate our data collection and measures operationalisation. Finally, we explain the study results, discussion, and managerial implications as well as demonstrating the limitations and future research.

\section{Background}

\subsection{Consumer intention to participate in an online community}

Online communities have emerged as an essential element of the knowledge economy and for organisations are often considered as a source of competitive advantage, as well as a channel for organisational learning (Balasubramanian \& Mahajan, 2001, Guo \& Sheffield, 2008; Procaci, Siqueira, Braz, \& Andrade, 2015).

According to the social constructivist theory, people can develop and improve their skills and creativity through solving workrelated problems in collaboration with capable peers (Jonassen, Howland, Moore, \& Marra, 2003). In other words, one of the important and effective methods for professional development occurs when those professionals are involved in discussions with their peers about their ideas, experiences, and collaboratively solve work-related problems. Wenger (1998) emphasises that knowledge creation occurs in communities when members are involved and participate in problem solving and when they share their ideas and knowledge through articulating, illustrating, and negotiating on the better alternative solutions to solve the problems. In general, there are three distinct and different groups of benefits that might be obtained from a regular community of practice: individual, community and organisational (Millen, Fontaine, \& Muller, 2002). At the individual level, they suggest that there are benefits that might be obtained from increased understanding of others' efforts and increased levels of trust. The community's members will have access to experts and resources within the subject area relevant to their work. On the other side, communities benefit from increased idea generation, better quality of knowledge, and more effective problem solving. According to Millen et al. (2002), the individual and community benefits will generate tangible benefits at the organisational level in the form of positive business outcomes for the organisation. Such benefits may include improved communication, successful projects, product innovation, a reduction in time spent accomplishing tasks, and the greater operational efficiency.

Members' participation has been acknowledged as both the key resource and the biggest challenge for the survival of online communities (Ardichvili, 2008; Ardichvili, Page, \& Wentling, 2003; Butler, 2001; Chiu, Hsu, \& Wang, 2006; Hsu et al., 2007; Park \& Yang, 2012; Wasko \& Faraj, 2005).

Regardless of their purpose, type, or environment in which they reside, online communities' survival largely depends on their ability to attract and retain members who are willing to actively participate in their communities (Butler, 2001; Wang, Butler, \& Ren, 2011). Assuming the critical relevance of participation for the survival of online communities, previous online community studies have largely been conducted with the aim of understanding what motivates people to participate in these social spaces. To inform their explanations, they have relied on the use of such theories as social cognitive theory (Bock \& Kim, 2002; Chiu et al., 2006); social capital theory (Chiu et al., 2006; Huysman \& Wulf, 2005); social exchange theory (Bock \& Kim, 2002; Faraj \& Johnson, 2011; Wang, 2007); sunk cost theory (Tiwana \& Bush, 2005); the technology acceptance model (Venkatesh, 2000); theories of social networks and Social Network Analysis (Faraj \& Johnson, 2011; Toral, Martínez-Torres, \& Barrero, 2010); critical mass theory (Raban, Moldovan, \& Jones, 2010); and resource-based theory (Butler, 2001). Through these theories, previous studies have provided different perspectives influenced by such areas as psychology, sociology, information technologies, organisational studies, human-computer interaction.

The participation of consumers in an online community is a key factor that determines the success of any online community in the long term (Koh \& Kim, 2004), because consumer participation in an online community will contribute to building long term relationships between the members of the community (Algesheimer, Dholakia, \& Herrmann, 2005). Participation in online community will guarantee a high level of consumer involvement with the online community, which may "reinforce the feelings that bind each member to the other community members, improve instruction on communal values, encourage conjoint behaviours and information sharing, and enable stronger group cohesion" (Casaló et al., 2010, p. 898). Continuing participation in an online community joint activities helps the community members achieve common goals (Bagozzi \& Dholakia, 2006) and is a key factor for community endurance (Koh \& Kim, 2004).

However, due to the difficulties regarding measuring consumer real behaviour, we focus on consumer intentions to participate. Both the theory of reasoned action (TRA) and theory of planned behaviour (TPB) show that consumers' intention directly affects their actual behaviour. Previous studies pointed out that consumer intentions measure consumer behaviour in the context of technology acceptance e.g., (Casaló et al., 2010; Karahanna, Straub, \& Chervany, 1999; Kim, Ferrin, \& Rao, 2008; Kim, Lee, \& Law, 2008; Sia, Lim, Leung, Lee, \& Huang, 2009). McKnight, Choudhury, and Kacmar (2002) pointed out that consumer behaviour intentions refers to a consumer will likely behave in a specified way, and both behaviour intentions and real behaviours are very highly associated (Venkatesh \& Davis, 2000). Therefore, we focus on the intention of consumer to participate as a good indicator of the level of the 
participation of consumer in online community.

\subsection{Innovation diffusion theory (IDT)}

Innovation diffusion theory (IDT) has received substantial empirical support in explaining consumer acceptance in several disciplines, specifically online shopping e.g. (Amaro \& Duarte, 2015; Hung, Yang, Yang, \& Chuang, 2011; Jensen, 2009; Lee, Hsieh, \& Hsu, 2011; Yu \& Wu, 2007). An innovation is "an idea, practice, or object that is perceived as new by an individual or another unit of adoption" (Rogers, 1995, p. 11). Diffusion, on the other hand, is "the process by which an innovation is communicated through certain channels over time among the members of a social system" (Rogers, 1995, p. 5). Therefore, the IDT theory argues that "potential users make decisions to adopt or reject an innovation based on beliefs that they form about the innovation" (Agarwal, 2000, p. 90).

Innovation diffusion theory provides a set of factors that influence consumer's intention to adopt new technologies. These factors are relative advantage, compatibility, complexity, trialability, and visibility. Of these factors, relative advantage and compatibility have provided the most constant explanation for consumer intention to adapt new technologies (Lu, Yang, Chau, \& Cao, 2011). Therefore, our study focus on examining the influence of perceived relative advantages and compatibility on the consumer intentions to participate in online travel community.

\subsection{Technology acceptance model (TAM)}

The Technology Acceptance Model proposed by Davis and Bagozzi (Bagozzi, Davis, \& Warshaw, 1992) appears to be the most widely used innovation adoption model. This model has been used in a variety of studies to explore the factors affecting individual's use of new technology (Mohammadi, 2015; Venkatesh \& Davis, 2000).

Based on the prior studies, numerous studies applied several theoretical perspectives in order to explain and understand consumers' acceptance and use of new technology. Of these, the TAM considers the most effective approach to investigating consumer acceptance and use of technology related application (Ayeh, 2015; Kim, Kim, \& Shin, 2009). The technology acceptance model was initially proposed by Davis (1986).

The TAM theory postulates that individuals' perceptions about ease of use and usefulness are two cognitive factors that determine their acceptance of information system. TAM has received substantial empirical support in explaining consumer acceptance of various types of technology e.g. technology based services (Zhu \& Chan, 2014), smart phones (Joo \& Sang, 2013) and the new media (Workman, 2014). In tourism context, numerous studies applied TAM to understand and explain consumer acceptance of new technology including hotel front office systems (Kim, Ferrin et al., 2008; Kim, Lee et al., 2008), consumer intention to shop travel online (Amaro \& Duarte, 2015), biometric systems adaption in hotels (Morosan, 2012), and restaurant computing systems (Ham, Kim, \& Forsythe, 2008). The findings of these studies show that perceived ease of use and perceived usefulness are crucial determinants of consumer acceptance of technology. Therefore, our study examines the important role of perceived ease of use and perceived usefulness in understanding consumer participation intention.

\subsection{Trust in an online travel community}

Trust is defined as the subjective belief that the online service provider will fulfil its transactional obligations, as those obligations are understood by the consumer (Kim, Ferrin et al., 2008; Kim, Lee et al., 2008). Prior studies consider trust as a key factor of success in the online context e.g. (Corritore, Kracher, \& Wiedenbeck, 2003; Elbeltagi \& Agag, 2016; Flavián, Guinalíu, \& Gurrea, 2006; Koufaris \& Hampton-Sosa, 2004) due to the high risk that customers perceive in the online environment (Harris \& Goode, 2004). Consequently, numerous empirical studies have been conducted in order to understand and determine the importance of trust in the online environment e.g. (Bart, Shankar, Sultan, \& Urban, 2005; Casaló, Flavián, \& Guinalíu, 2011; Flavián et al., 2006; Schlosser, White, \& Lloyd, 2006).

Focussing on the cognitive component of trust, it consists of three distinct factors including honest, competence and benevolence, which all contribute to consumers' perceptions of trust in an online travel community, as suggested by Flavián et al. (2006), McKnight et al. (2002), and Casaló et al. (2011). Honesty reflects the belief that other community members will fulfil their promises and keep their word (Doney \& Cannon, 1997). Coulter and Coulter (2002) defined competence as the perceived skill and ability of the other party. In this study competence refers to the consumer perceived skills and knowledge of other community members. Benevolence means that community members intend to support, help and care for other community members (Ridings, Gefen, \& Arinze, 2002).

\section{Theoretical development and research hypotheses}

Based on the preceding review, this study integrates relative advantages, compatibility, perceived ease of use, perceived usefulness, trust, and attitudes as antecedents of the intentions of consumer to participate in an online travel community in a comprehensive framework. Fig. 1 shows our conceptual framework. The model illustrates the antecedents of consumer intentions to participate in an online community and intention to purchase travel online and intention to recommend the online community as outcomes. As well as the moderating effect of religiosity on the relationship between trust, attitude, intention to participate, and intention to purchase travel online. The hypothesized relationships are discussed in the following section.

\subsection{Perceived relative advantages, compatibility, attitudes, and intention to participate}

Perceived relative advantages are one of the Innovations Diffusion Theory essence constructs. For the purposes of the current study, perceived relative advantage is defined as the degree to which online travel community provides members with benefits e.g. convenience, lower price, time saving and relations with persons who share common interests. In the field of tourism and ecommerce, a significant and positive relationship between perceived relative advantages and consumer behaviour intention and attitudes is supported by a wide variety of studies e.g., (Amaro \& Duarte, 2015; Jensen, 2009; Kamarulzaman, 2007; Lu et al., 2011; Moital, Vaughan, Edwards, \& Peres, 2009). Therefore, customers who perceive the relative advantages of online travel community are more likely to participate in online travel community.

Perceived compatibility is a construct borrowed from the IDT defined as "the degree to which an innovation is perceived as being consistent with existing values, past experiences, and needs of potential adopters" (Rogers, 1995, p. 15). For the purpose of the current study, we define compatibility as the extent to which online community members believe that participating in online community will fit their needs, lifestyle, and shopping preference.

Research has supported the positive and significant relationship between compatibility and attitude towards online shopping (e.g. Amaro \& Duarte, 2015; Chen, Gillenson, \& Sherrell, 2002; 


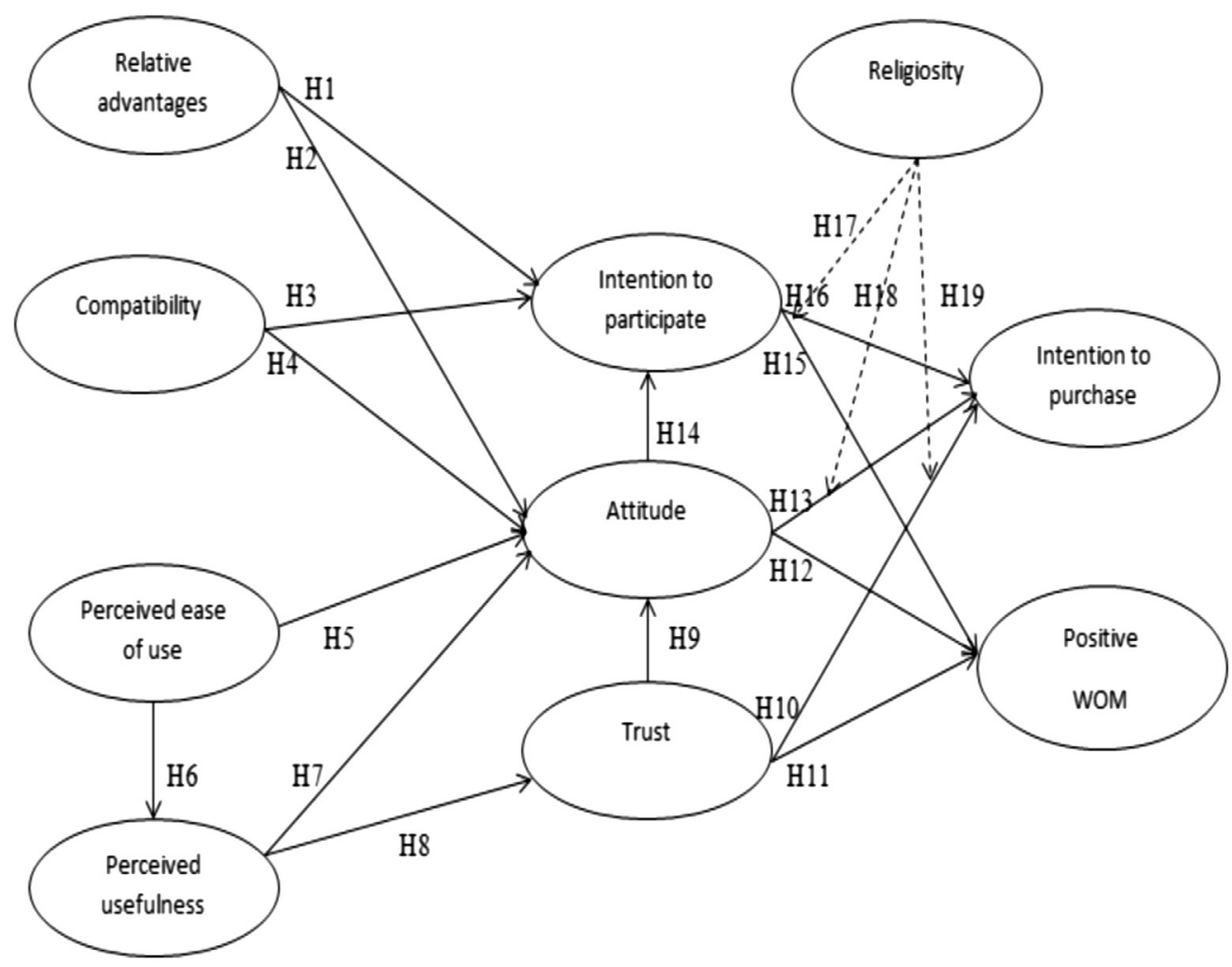

Fig. 1. Research conceptual framework.

Vijayasarathy, 2004). Bellman, Lohse, and Johnson (1999) reported that individuals who spent a considerable amount of time using the Internet and other related technologies such as e-mail in their job or personal life would be more likely to shop online.

Compatibility captures the consistency between an innovation and the potential adopters' existing values, current needs, and present lifestyle. In the context of travel, peoples' lifestyles will strongly affect their decision to adopt the technology. Amaro and Duarte (2015) and Li and Buhalis (2006) pointed out that perceived compatibility positively influence consumer behaviour intention. Thus, the authors propose the following hypotheses:

Hypothesis 1. Perceived relative advantages have a direct and positive influence on consumer intention to participate in an online travel community.

Hypothesis 2. Perceived relative advantages have a direct and positive influence on consumer attitude toward an online travel community.

Hypothesis 3. Compatibility has a direct and positive influence on consumer intention to participate in an online travel community.

Hypothesis 4. Compatibility has a direct and positive influence on consumer attitude toward an online travel community.

\subsection{Perceived ease of use, perceived usefulness, attitude, and trust}

Perceived ease of use has been defined as "the degree to which a person believes that using a particular system would be free of effort" Davis (1989, p.320). In the current study, perceived ease of use is defined as the extent to which the online travel customer believes that participating in online travel community will be free from effort.

According to TAM, perceived ease-of-use, perceived usefulness, attitude and intention have been theorized to be the prime influencers for usage and acceptance attitude (Agag \& El-Masry, 2016;
Akman \& Mishra, 2015; Hsu \& Lin, 2008; Lai, Hsu, \& Chung, 2010; Lim, Lim, \& Heinrichs, 2008).

Research has supported the positive and significant relationship between ease of use and attitude towards online shopping (e.g. Agag \& El-Masry, 2016; Ayeh, 2015; Morosan \& Jeong, 2008; Zhu \& Chan, 2014). TAM implies that, other things being equal, an online shopping Web site perceived to be easier to use is more likely to induce perception of usefulness. Davis, Bagozzi, and Warshaw (1989) argued that improvements in ease of use may also be instrumental, contributing to increased performance. To the extent that increased ease of use leads to improved performance, ease of use would have a direct effect on perceived usefulness (Venkatesh \& Davis, 2000). Also, it is generally believed that a system will be regarded as more useful if it is easy to use. For example, studies by Morosan (2012), Kim, Ferrin et al. (2008), Kim, Lee et al. (2008), and Ayeh (2015) and Agag and El-Masry (2016) among others, offer strong empirical support for a positive relationship between perceived usefulness and ease of use. Therefore, participation in online travel community will be more useful if it easy to use.

Also, Davis (1989, p. 320) conceptualised perceived usefulness as "the degree to which a person believes that using a particular system would enhance his or her job performance". In our study, perceived usefulness refers to the extent to which the consumer believes that participating in an online travel community improves his/her travel planning. Previous studies support the positive and significant relationship between perceived usefulness and consumer attitude e.g. (Agag \& El-Masry, 2016; Ayeh, Au, \& Law, 2013; Joo \& Sang, 2013; Persico, Manca, \& Pozzi, 2014; Workman, 2014).

While some researchers Palvia (2009) proposed 'perceived usefulness' as an antecedent to transaction intention based on technology acceptance model (TAM), no existing study specified perceived usefulness as an antecedent to trust. As Gefen, Karahanna, and Straub (2003) suggested, it would make more sense to postulate that perceived usefulness is a consequence, not 
an antecedent, of trust in an e-commerce firm. A business relationship developed based on trust provides a measure of subjective guarantee that the e-commerce firm will behave with good will and that the outcome of a transaction will be fair and favourable, and thus increase the benefits of transacting on the e-commerce Web site that consumers come to perceive as more useful (Gefen et al., 2003). Therefore, we decided to rule out perceived usefulness as a trust antecedent from our model. Hence, the hypotheses:

Hypothesis 5. Perceived ease of use has a direct and positive influence on consumer attitude toward online travel community.

Hypothesis 6. Perceived ease of use has a direct and positive influence on perceived usefulness.

Hypothesis 7. Perceived usefulness has a direct and positive influence on consumer attitude toward online travel community.

Hypothesis 8. Perceived usefulness has a direct and positive influence on consumer trust.

\subsection{Trust, attitude, intention to purchase travel online, and WOM}

Trust is conceptualised as the subjective belief that the online service provider will fulfil its transactional obligations, as those obligations are understood by the consumer (Kim, Ferrin et al., 2008; Kim, Lee et al., 2008). Despite the importance of trust, Kim, Chung, and Lee (2011) state that there is a lack of research regarding perceived trust in online shopping for tourism products and services. Therefore, it is relevant to add trust since the few studies that have considered trust in online travel shopping have also produced mixed results. For example, while Wen (2010) claimed that consumers' trust in online shopping had a positive effect on intentions to purchase travel online, Kamarulzaman (2007) did not find a direct effect on the adoption of online travel shopping. Therefore, it is relevant to incorporate trust in our model.

In the e-commerce field, several prior studies have confirmed the positive link between trust and the intentions to purchase online (Chiu, Huang, \& Hui, 2010; Gefen et al., 2003; Kim, Xu, \& Gupta, 2012). In the field of tourism and e-commerce, a significant and positive relationship between trust and purchase intention is supported by a variety of studies (e.g., Agag \& El-Masry, 2016; Amaro \& Duarte, 2015; Bigne, Sanz, Ruiz, \& Aldas, 2010; Escobar-Rodríguez \& Carvajal-Trujillo, 2014; Kim et al., 2011; Ponte, Carvajal-Trujill, \& Escobar-Rodr, 2015; Sanz-Blas, Ruiz-Mafe, \& Perez, 2014).

Alsajjan and Dennis (2010) found that trust influences consumer attitude and intention to engage in behaviour. Consumers who trust in online service provider will have a positive attitude toward this online service provider and more likely to repurchase. In support of this notion, Amaro and Duarte (2015) and Ashraf, Thongpapanl, and Auh (2014) and Agag and El-Masry (2016), found a significant path from trust to customer attitude and repurchase intentions. Other research has found that trust influences word of mouth (Lien \& Cao, 2014). Therefore, consumers who trust in an online travel community are more likely to spread positive word of mouth. Hence, the following hypotheses are proposed.

Hypothesis 9. Consumer trust has a direct and positive influence on their attitude toward online travel community.

Hypothesis 10. Consumer trust has a direct and positive influence on their intention to purchase travel online.

Hypothesis 11. Consumer trust has a direct and positive influence on their intention to recommend this online travel community.

\subsection{Attitude, WOM, and consumer behaviour intentions}

Based on TAM, intentions are the result of attitudes towards the outcomes of behaviour (Davis, 1986). In the travel context, numerous studies have pointed out that attitude towards online shopping positively effects intentions to purchase travel online e.g. (Agag \& El-Masry, 2016; Amaro \& Duarte, 2015; Bigne et al., 2010; Morosan \& Jeong, 2008) found that attitude had the strongest influence on consumer intentions to purchase travel online.

Attitude is a crucial determinant of behaviour intention and has a positive influence on consumer intention to use information system (Agag \& El-Masry, 2016; Yang \& Yoo, 2004). The relationship between attitude and the intention of consumer to participate has been supported by Casaló et al. (2010). Therefore, consumers who have a positive attitude toward online travel community are more likely to participate.

Regarding the link between attitude and word of mouth, Shih, Lai, and Cheng (2013) pointed out that attitude has a positive influence on word of mouth intention. In support of this notion, Lien and Cao (2014), found a significant path from customer attitude to word of mouth. Therefore, consumers who have a positive attitude toward online travel community are more likely to spread positive word of mouth about this online community.

In online communities' context, a customer may promote the products and services of the online community because the online community offers value greater than the value offered by competitors. Therefore, Consumers will response to this greater value by remaining loyal to these communities and promote their products and services by spreading positive word of mouth. Furthermore, Casaló et al. (2010) and Muñiz and Schau (2005) found that the intention of consumers to participate in an online travel community has a positive and significant effect on consumer positive word of mouth.

Algesheimer et al. (2005) pointed out that consumer intention to participate in an online community effects consumer behaviours related to the firm that hosts the network. Andersen (2005) found that participation in online community may improve consumer loyalty. In tourism context, prior studies have found out that consumer intention to purchase and use the online travel community is a key aspect of the intention to participate in an online travel community (Algesheimer et al., 2005; Casaló et al., 2010). Therefore, in the travel sector, we propose.

Hypothesis 12. Consumer attitude toward online travel community has a direct and positive influence on positive WOM.

Hypothesis 13. Consumer attitude toward online travel community has a direct and positive influence on intention to purchase travel online.

Hypothesis 14. Consumer attitude has a direct and positive influence on consumer intention to participate in an online travel community.

Hypothesis 15. Consumer intention to participate in an online travel community has a direct and positive influence on positive WOM.

Hypothesis 16. Consumer intention to participate in an online travel community has a direct and positive influence on intention to purchase travel online.

\subsection{Moderating effects of religiosity}

Religiosity has been recognized as a crucial social force that impacts human behaviour. Prior studies have pointed out that religiosity can be a key factor of consumption patterns (Cleveland, Laroche, \& Hallab, 2013) and selected store patronage behaviour (Alam, Mohd, \& Hisham, 2011).

Kirillovaa, Gilmetdinovab, and Lehtoc (2014) suggested that the differences of religious between hosts and guests do not only affect the interactions but also influence the very presence of hospitality in a region. In some Muslim countries e.g. Egypt, tourism is 
discouraged due to its potential negative effects on host communities (Din, 1989). Joseph and Kavoori (2001) pointed out that tourism represents a potential threat to religious habits and local traditions. Terzidou, Stylidis, and Szivas (2008) pointed out that religion is a key factor in the relationships between host and guest even when both tourists and the local people have the same religious backgrounds. Ranganathan and Henley (2007) pointed out that religiosity has a positive influence on behaviour intention and this subsequently may positively affect attitude.

This study examines the moderating role of religiosity on the association between consumer intention to participate, attitude, trust, and intention to purchase travel online. The behaviour and attitude of consumers at the website may differ based on their religiosity (Egresi, Kara, \& Bayram, 2012). All the above leads us to formulate the following:

Hypothesis 17. Religiosity moderates the relationship between consumer intention to participate and intention to purchase travel online.

Hypothesis 18. Religiosity moderates the relationship between consumer attitude and intention to purchase travel online.

Hypothesis 19. Religiosity moderates the relationship between consumer trust and intention to purchase travel online.

\section{Research methodology}

We conducted empirical study on online travel communities in Egypt in order to test the proposed hypotheses. Our study composed of two approaches, a qualitative phase followed by a quantitative. Using the mixed methods contributes to the validity, reliability, and quality of the data (Babbie, 2004). In regard to the qualitative stage, we performed two focus groups one with the online travel communities' managers and another focus groups with a set of consumers. Regarding the qualitative sampling, 30 managers of firm-hosted online travel community in Egypt accepted to participate in the first focus group. The second focus group consisted of 150 consumers who had registered as a member of the online travel community selected. Semi-structured interviews have been used to collect the qualitative information from the managers and the consumers. We performed an inductive analysis as well as subjective interpretation of the contents collected. Particularly, we identified the factors that determine consumer intention to participate in firm-hosted online travel community. This qualitative phase contributed to the study variables measurement scales as well as to the explanation of the quantitative results.

\subsection{Sampling and data collection}

Quantitative data were collected using survey strategy through questionnaires to address different levels of the study. The target population of the current study comprises all consumers who are members of the online travel communities in Egypt and who had special interest in travel.

The main aim of this study is to understand consumers' behaviour regardless of the characteristics of online travel community. We asked respondents to fill the questionnaire based on their favourite online community usage experience. They were questioned regarding their perception of the online travel community of which they were a member. Respondents required to be registered as a member of the online travel community selected. However, since there is no a list of online travel community members across Egypt it is impossible to select our sample from the population directly. Thus, convenience sampling was used to collect data (San Martín \& Herrero, 2012).

In order to preserve a certain level of traffic as a minimum as well as total membership (Ridings et al., 2002), 50 online travel communities were chosen based on their activity level and have large members. 35 online travel communities accepted to participate in our survey. The survey was posted to online travel store site with a request for participation, provided respondents with information on the purpose of the study, the approximate time to fill out the questionnaire, and a banner with a hyperlink connecting to our web survey.

A pilot test was conducted to assess the validity and reliability of the research instrument.

The instrument was given to a group of forty five individuals who mentioned that they registered in online travel community selected. Their comments resulted in refinement of the instrument in terms of its length, format, readability, and clarity. Twenty online travel community managers were also asked to review the questionnaire. This review resulted in elimination of a specific item measuring trust. The exclusion of this item did not pose a major threat to construct validity, since there were three additional items assessing trust. Some wording changes were also made.

The questionnaire was available online between November 15 th of 2014 and January 20th of 2015. Eventually, we invite 650 members to complete the questionnaire, and 510 effective respondents were obtained, But 15 who sent incomplete questionnaires were omitted from the analyses. Therefore, a total of 495 responses were considered to be valid for further analyses (response rate is 76.15\%). The high response rate may be due to the questionnaire was designed in such a way that only 15 min were needed to complete it.

Of these 495 participants, 280 were men (57.0\%) and 215 were women (43.0\%). The majority of respondents were aged between 30 and 40 (40.0\%), had bachelor degree (34.0\%), and had engaged in online shopping less than three times within the past six months (42.0\%). The most recent online shopping experience for the majority of respondents was within the previous 2 years (42.0\%) and the majority of online shopping had a monthly income of $£ 1000$ or below (59.0\%).

Bartlett, Kotrlik, and Higgins (2010) pointed out that when determining the sample size for an SEM research, 10 observations per indicator (independent variable) is recommended. Since 495 cases were collected, the current research sample size considers adequate for successive analyses with structural equation modelling.

\subsection{Questionnaire and measurements}

The questionnaire for the present study was divided into two main sections. The first section contained questions to measure each construct based on existing measures or adapted from similar scales. It should be noted that all constructs have a reflective measurement. The last section of the questionnaire consisted of questions regarding respondents' demographic characteristics e.g. gender, age and education level. To prevent duplicate responses, the option to control and remove duplicate responses by IP was used. The research model has ten constructs, each having items that are gauged by Likert scale ( 1 = strongly disagree and $5=$ strongly agree).

Four items borrowed from previously developed scales were used to measure perceived relative advantages (Amaro \& Duarte, 2015; Jensen, 2009; Kim et al., 2011; Limayem, Khalifa, \& Frini, 2000), and modified based on consumers' interviews and pilot study. In conceptualizing the compatibility, this study uses three items to assess the compatibility borrowed from Vijayasarathy (2004) and Jan and Contreras (2011). The variables of perceived ease of use and perceived usefulness in this study were operationalized with three items each as suggested by Davis (1989) scales. Perceived usefulness items reflect the consumer believes 
that participating in an online travel community improves his/her travel planning. Perceived ease of use items reflect the ease of participating in online travel community. Consumer trust measures were adapted from Morgan and Hunt (1994) and Kim et al. (2011), four items were adopted and modified based on consumers' interviews and pilot study. These items measure the integrity and reliability of online travel community as well as the trustworthiness of this online community. Attitude and intention to participate in online travel community in this study were operationalized with two items each as proposed by prior studies (Algesheimer et al., 2005; Casaló et al., 2010; Cheng, Lam, \& Yeung, 2006; Hsu, Yen, Chiu, \& Chang, 2006). We conceptualize intentions to purchase travel online as containing of purchase intention and continued interaction. Intentions to purchase travel online were measured by three items borrowed from Kim et al. (2012) and Algesheimer et al. (2005). The scale for word of mouth was adapted from Choi and Choi (2014). Finally, religiosity was measured with a 6-item scale developed by Allport and Ross (1967) and Swimberghe, Flurry, and Parker (2011). The first three items of the scale represent intrinsic religiosity, while the other three represent extrinsic religiosity. An example of an intrinsic religiosity item is, "It is important to me to spend time in private thought and prayer." An example of an extrinsic religiosity item is, "I go to religious service because it helps me to make friends."

We applied the partial least squares (PLS-SEM), WarpPLS 3.0 programme was utilized to validate the measures and test the hypotheses. This approach has been used as the investigated phenomenon is new and the research aims at generation of theory rather than confirmation a theory (Urbach \& Ahlemann, 2010). furthermore, a PLS approach does not require a normal distribution, as opposed to covariance-based approaches, which requires a normal distribution (Henseler, Ringle, \& Sarstedt, 2012), Finally, this approach incorporates both reflective and formative measures (Hair, Ringle, Hult, \& Sars, 2013).

\section{Results}

The evaluation of a conceptual framework using PLS analysis contains two steps. The first step includes the evaluation of the measurement (outer) model. The second step involves the evaluation of the structural (inner).

\subsection{Measurement model}

In order to satisfy the criterion of multivariate normality tests of normality, namely skewness, kurtosis, and Mahalanobis distance statistics (Bagozzi \& Yi, 1988), were conducted for all the constructs, Table 6 (see Appendix). These indicated no departure from normality. The psychometric properties of the constructs were assessed by calculating the Cronbach's alpha reliability coefficient (Nunnally \& Bernstein, 1994) (see Table 1).

The first step in evaluating a research model is to present the measurement model results to examine the reliability and validity of the measures used to represent each construct (Chin, 2010). These results are shown in Tables 2 and 3. We also performed tests for multicollinearity due to the relatively high correlations among some of the constructs. All constructs had variance inflation factors (VIF) values less than 2.8, which is within the cut off level of 3.0.

All items loaded on to the corresponding latent variable structure and all items exhibit loadings greater than 0.7. All constructs exhibit adequate internal consistency reliability as the Chronbach alpha coefficients exceed the 0.7 (Table 2). All the remaining constructs showed good internal consistency reliability.

The measurement model also exhibited significant convergent validity as a cross-loading matrix exhibits no cross loading that
Table 1

Sample profile.

\begin{tabular}{llrr}
\hline Variable & Categories & Frequency & Percept \\
\hline Gender & Male & 280 & $57.0 \%$ \\
Age & Female & 215 & $43.0 \%$ \\
& $<20$ & 96 & $19.0 \%$ \\
& $20<30$ & 120 & $24.0 \%$ \\
Monthly income & $30>40$ & 200 & $40.0 \%$ \\
& $<40$ & 79 & $16.0 \%$ \\
Education & $£ 1000$ or below & 290 & $59.0 \%$ \\
& $£ 1001-2000$ & 156 & $32.0 \%$ \\
& $£ 2001-3000$ & 49 & $9.0 \%$ \\
& High school & 70 & $14.0 \%$ \\
Experience & Bachelor degree & 170 & $34.0 \%$ \\
& Diploma & 110 & $22.0 \%$ \\
Internet access location & Master or doctorate & 140 & $28.0 \%$ \\
& other & 5 & $2.0 \%$ \\
& $<2$ & 211 & $42.0 \%$ \\
& $2<5$ & 178 & $36.0 \%$ \\
& $>5$ & 106 & $21.0 \%$ \\
& At home & 319 & $64.0 \%$ \\
& At work & 98 & $20.0 \%$ \\
& At school & 12 & $3.0 \%$ \\
& In internet café & 60 & $11.0 \%$ \\
& In a friend place & 6 & $2.0 \%$ \\
\hline
\end{tabular}

exceeds the with-in row and column loadings. Discriminant validity is considered in two steps. First, the Fornell and Larcker (1981) criterion is used to test whether the square root of a construct's AVE is higher than the correlations between it and any other construct within the model. Second, the factor loading of an item on its associated construct should be greater than the loading of another non-construct item on that construct. Table 2 shows the result of this analysis and reports the latent variable correlation matrix with the AVE on the diagonal. Therefore we conclude that measurement model exhibits good discriminant validity and meets the Fornell and Larcker (1981). The Maximum Shared Squared Variance (MSV) and the Average Squared Variance (ASV) were used to test the discriminant validity of the measurement model. The MSV and the ASV results need to be lesser than the AVE for the discriminant validity (Hair, Black, Babin, \& Anderson, 2010). Table 3 shows that the MSV and the ASV results are lesser that the AVE values which means that the discriminant values hold and the measurement model is according to the assumptions which were initially made.

In order to assess potential non-response bias, we tested whether there were differences among respondents and nonrespondents; a survey has been sent to all non-respondents of the original survey. A total of 370 responses were received from non-respondents of the initial survey. We tested the significance of differences between averages in the main sample and a follow-up sample the analysis did not reveal any significant differences between respondents and non-respondents. We therefore excluded the possibility of non-response bias.

A principal component factor analysis was conducted and the results excluded the potential threat of common methods bias. The largest factor accounted for $26.24 \%$ (the variances explained ranges from $13.61 \%$ to $26.24 \%$ ) and no general factor accounted for more than $50 \%$ of variance, indicating that common method bias may not be a serious problem in the data set.

\subsection{Structural model assessment}

Since the measurement model evaluation provided evidence of reliability and validity, the structural model was examined to evaluate the hypothesised relationships among the constructs in the research model (Hair et al., 2013). According to Henseler et al. (2012) and Hair et al. (2013) recommendations, the structural model proposed in the current study was evaluated with several 
Table 2

Loadings and cross-loadings of measurement items.

\begin{tabular}{|c|c|c|c|c|c|c|c|c|c|c|c|}
\hline Items & RLD & COP & EOU & USF & TRU & ATT & PIN & WOM & INP & REL & $\mathrm{p}$ value \\
\hline RED1 & 0.836 & 0.384 & 0.182 & 0.371 & 0.280 & 0.483 & 0.106 & 0.176 & 0.278 & 0.389 & $<0.001$ \\
\hline RED2 & 0.871 & 0.293 & 0.028 & 0.178 & 0.273 & 0.273 & 0.043 & 0.029 & 0.029 & 0.412 & $<0.001$ \\
\hline RED3 & 0.807 & 0.517 & 0.463 & 0.274 & 0.419 & 0.178 & 0.190 & 0.178 & 0.371 & 0.218 & $<0.001$ \\
\hline RED4 & 0.794 & 0.281 & 0.374 & 0.619 & 0.219 & 0.278 & 0.029 & 0.367 & 0.270 & 0.410 & $<0.001$ \\
\hline COP1 & 0.461 & 0.841 & 0.419 & 0.273 & 0.126 & 0.039 & 0.379 & 0.479 & 0.478 & 0.172 & $<0.001$ \\
\hline COP2 & 0.130 & 0.902 & 0.191 & 0.410 & 0.617 & 0.319 & 0.630 & 0.582 & 0.639 & 0.095 & $<0.001$ \\
\hline COP3 & 0.362 & 0.809 & 0.310 & 0.117 & 0.291 & 0.572 & 0.127 & 0.028 & 0.378 & 0.318 & $<0.001$ \\
\hline EOU1 & 0.481 & 0.258 & 0.782 & 0.371 & 0.117 & 0.389 & 0.345 & 0.285 & 0.219 & 0.471 & $<0.001$ \\
\hline EOU2 & 0.391 & 0.556 & 0.882 & 0.008 & 0.261 & 0.571 & 0.471 & 0.627 & 0.471 & 0.210 & $<0.001$ \\
\hline EOU3 & 0.281 & 0.517 & 0.901 & 0.372 & 0.378 & 0.502 & 0.479 & 0.283 & 0.218 & 0.290 & $<0.001$ \\
\hline USF1 & 0.436 & 0.141 & 0.124 & 0.917 & 0.471 & 0.127 & 0.381 & 0.472 & 0.187 & 0.473 & $<0.001$ \\
\hline USF2 & 0.321 & 0.414 & 0.185 & 0.814 & 0.309 & 0.470 & 0.370 & 0.188 & 0.217 & 0.279 & $<0.001$ \\
\hline USF3 & 0.391 & 0.214 & 0.058 & 0.792 & 0.049 & 0.510 & 0.029 & 0.276 & 0.480 & 0.192 & $<0.001$ \\
\hline TRU1 & 0.221 & 0.156 & 0.581 & 0.388 & 0.821 & 0.231 & 0.368 & 0.038 & 0.039 & 0.389 & $<0.001$ \\
\hline TRU2 & 0.584 & 0.312 & 0.263 & 0.142 & 0.727 & 0.321 & 0.584 & 0.389 & 0.382 & 0.289 & $<0.001$ \\
\hline TRU3 & 0.213 & 0.451 & 0.580 & 0.049 & 0.789 & 0.418 & 0.603 & 0.572 & 0.182 & 0.189 & $<0.001$ \\
\hline TRU4 & 0.164 & 0.613 & 0.218 & 0.217 & 0.792 & 0.379 & 0.278 & 0.604 & 0.378 & 0.218 & $<0.001$ \\
\hline ATT1 & 0.214 & 0.029 & 0.049 & 0.261 & 0.283 & 0.847 & 0.206 & 0.571 & 0.128 & 0.139 & $<0.001$ \\
\hline ATT2 & 0.566 & 0.591 & 0.417 & 0.569 & 0.039 & 0.790 & 0.018 & 0.172 & 0.473 & 0.483 & $<0.001$ \\
\hline PIN1 & 0.171 & 0.481 & 0.701 & 0.471 & 0.372 & 0.237 & 0.867 & 0.571 & 0.472 & 0.630 & $<0.001$ \\
\hline PIN2 & 0.342 & 0.187 & 0.231 & 0.118 & 0.291 & 0.478 & 0.845 & 0.305 & 0.178 & 0.038 & $<0.001$ \\
\hline WOM1 & 0.145 & 0.490 & 0.178 & 0.271 & 0.217 & 0.478 & 0.264 & 0.904 & 0.581 & 0.418 & $<0.001$ \\
\hline WOM2 & 0.612 & 0.251 & 0.019 & 0.221 & 0.282 & 0.189 & 0.561 & 0.782 & 0.471 & 0.302 & $<0.001$ \\
\hline WOM3 & 0.585 & 0.154 & 0.604 & 0.007 & 0.029 & 0.378 & 0.271 & 0.784 & 0.481 & 0.182 & $<0.001$ \\
\hline INP1 & 0.461 & 0.314 & 0.374 & 0.317 & 0.293 & 0.347 & 0.379 & 0.162 & 0.877 & 0.293 & $<0.001$ \\
\hline INP2 & 0.047 & 0.461 & 0.475 & 0.046 & 0.219 & 0.278 & 0.581 & 0.471 & 0.937 & 0.630 & $<0.001$ \\
\hline INP3 & 0.510 & 0.218 & 0.283 & 0.217 & 0.039 & 0.428 & 0.381 & 0.039 & 0.780 & 0.392 & $<0.001$ \\
\hline REL1 & 0.085 & 0.391 & 0.318 & 0.117 & 0.178 & 0.278 & 0.179 & 0.471 & 0.172 & 0.791 & $<0.001$ \\
\hline REL2 & 0.284 & 0.560 & 0.271 & 0.056 & 0.189 & 0.170 & 0.392 & 0.283 & 0.364 & 0.839 & $<0.001$ \\
\hline REL3 & 0.419 & 0.179 & 0.591 & 0.386 & 0.574 & 0.627 & 0.180 & 0.028 & 0.378 & 0.793 & $<0.001$ \\
\hline REL4 & 0.318 & 0.480 & 0.217 & 0.562 & 0.394 & 0.278 & 0.091 & 0.293 & 0.182 & 0.837 & $<0.001$ \\
\hline REL5 & 0.481 & 0.039 & 0.501 & 0.316 & 0.490 & 0.382 & 0.189 & 0.182 & 0.371 & 0.795 & $<0.001$ \\
\hline REL6 & 0.112 & 0.173 & 0.174 & 0.215 & 0.273 & 0.262 & 0.573 & 0.206 & 0.105 & 0.799 & $<0.001$ \\
\hline
\end{tabular}

Notes:

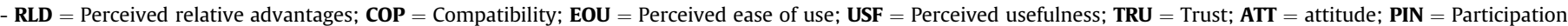
intention; WOM = Word of mouth; INP = Intention to purchase; $\mathbf{R E L}=$ Religiosity.

- Bolded items are factor loadings.

Table 3

Results of composite reliability and convergent/discriminant validity testing.

\begin{tabular}{|c|c|c|c|c|c|c|c|c|c|c|c|c|c|c|c|}
\hline \multirow[t]{2}{*}{ Construct } & \multirow[t]{2}{*}{ Composite reliability } & \multirow[t]{2}{*}{ Coronbach alpha } & \multirow[t]{2}{*}{ AVT } & \multirow[t]{2}{*}{ MSV } & \multirow[t]{2}{*}{ ASV } & \multicolumn{10}{|c|}{ Correlations and square roots of AVE } \\
\hline & & & & & & RLD & COP & EOU & USF & TRU & ATT & PIN & WOM & INP & REL \\
\hline RLD & 0.865 & 0.809 & 0.672 & 0.502 & 0.291 & $(0.758)$ & & & & & & & & & \\
\hline COP & 0.923 & 0.887 & 0.574 & 0.474 & 0.204 & 0.635 & $(0.806)$ & & & & & & & & \\
\hline EOU & 0.891 & 0.846 & 0601 & 0.485 & 0.172 & 0.481 & 0.735 & $(0.782)$ & & & & & & & \\
\hline USF & 0.865 & 0.793 & 0.618 & 0.374 & 0.261 & 0.703 & 0.781 & 0.621 & $(0.771)$ & & & & & & \\
\hline TRU & 0.879 & 0.854 & 0.567 & 0.519 & 0.183 & 0.681 & 0.601 & 0.583 & 0.639 & $(0.842)$ & & & & & \\
\hline ATT & 0.857 & 0.830 & 0.721 & 0.396 & 0.094 & 0.727 & 0.735 & 0.737 & 0.700 & 0.819 & $(0.773)$ & & & & \\
\hline SAT & 0.890 & 0.834 & 0.589 & 0450 & 0.247 & 0.687 & 0.697 & 0.632 & 0.642 & 0.637 & 0.708 & $(0.794)$ & & & \\
\hline PIN & 0.879 & 0.860 & 0.706 & 0.294 & 0.031 & 0.710 & 0.738 & 0.522 & 0.682 & 0.598 & 0.597 & 0.692 & $(0.812)$ & & \\
\hline WOM & 0.857 & 0.820 & 0.659 & 0.418 & 0.270 & 0.720 & 0.710 & 0.662 & 0.602 & 0.708 & 0.706 & 0.791 & 0.629 & $(0.832)$ & \\
\hline INP & 0.849 & 0.827 & 0.648 & 0.384 & 0.061 & 0.592 & 0.737 & 0.696 & 0.647 & 0.678 & 0.640 & 0.498 & 0.704 & 0.622 & $(0.803)$ \\
\hline REL & 0.873 & 0831 & 0649 & 0.412 & 0.149 & 0.687 & 0.598 & 0.602 & 0.537 & 0.485 & 0.715 & 0.539 & 0.674 & 0.697 & $0.793 \quad(0.741)$ \\
\hline
\end{tabular}

Note. Composite Reliability (CR), Average Variance Extracted (AVE), Maximum Shared Squared Variance (MSV), and Average Shared Squared Variance (ASV).

measures.

The model explains $39 \%$ of variance for perceived usefulness, $71 \%$ of variance for consumer trust, $53 \%$ of variance for attitude, $74 \%$ of variance for intention to participate, $78 \%$ of variance for intention to purchase, and $67 \%$ of variance for positive WOM. To test $\mathrm{H} 1-\mathrm{H} 19$, we tested the structural equation model in Fig. 2. The global fit indicators were acceptable, APC $=(0.174, \mathrm{p}<0.001)$, ARS $=(0.782$, $\mathrm{p}<0.001)$, AARS $=(0.749, \mathrm{p}<0.001)$, AVIF $=(2.841)$, and $\mathrm{GOF}=(0.726)$.

The estimated standardized structural coefficients for the hypothesized relationships between constructs and their significance are shown in Table 4. The results show that all hypothesized relationships are supported except $\mathrm{H} 1$ and $\mathrm{H} 17$.
The first hypothesis that predicted that perceived relative advantages of online travel community would positively affect intentions to participate in online travel community was not supported ( $\beta=0.00, \mathrm{p}=0.24$ ). Regarding the relationships between relative advantages and attitude, our findings support the favourable effect of perceived relative advantages on attitude $(\beta=0.41, \mathrm{p}<0.001)$.

As $\mathrm{H} 3$ and $\mathrm{H} 4$ predict, the study found significant positive impacts of compatibility on intention to participate and attitude, the study found significant positive impacts of compatibility on intention to participate $(\beta=0.39, \mathrm{p}<0.001)$ and attitude $(\beta=0.56$, $\mathrm{p}<0.001$ ).

In accord with $\mathrm{H} 5$, our findings support the favourable effect of 


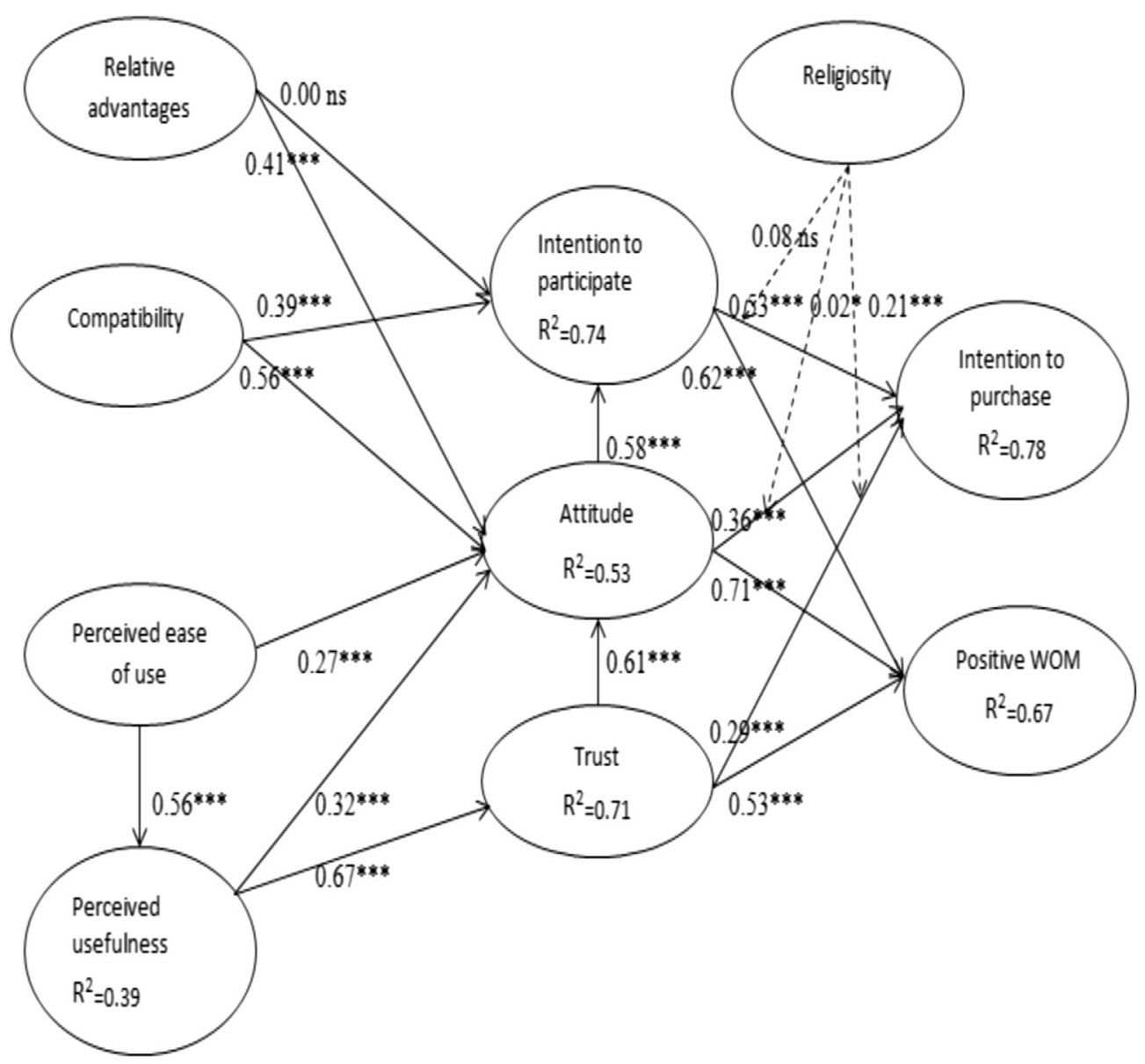

Fig. 2. PLS results of research model of main test.

Table 4

Results of hypotheses testing.

\begin{tabular}{lllll}
\hline Hypotheses & Path directions & Beta Values $(\beta)$ & P value & Result \\
\hline H1 & RLD $\rightarrow$ PIN & 0.00 & 0.24 & Rejected \\
H2 & RLD $\rightarrow$ ATT & 0.41 & 0.001 & Accepted \\
H3 & COP $\rightarrow$ PIN & 0.39 & 0.001 & Accepted \\
H4 & COP $\rightarrow$ ATT & 0.56 & 0.001 & Accepted \\
H5 & EOU $\rightarrow$ ATT & 0.27 & 0.001 & Accepted \\
H6 & EOU $\rightarrow$ USF & 0.56 & 0.001 & Accepted \\
H7 & USF $\rightarrow$ ATT & 0.32 & 0.001 & Accepted \\
H8 & USF $\rightarrow$ TRU & 0.67 & 0.001 & Accepted \\
H9 & TRU $\rightarrow$ ATT & 0.61 & 0.001 & Accepted \\
H10 & TRU $\rightarrow$ INP & 0.29 & 0.001 & Accepted \\
H11 & TRU $\rightarrow$ WOM & 0.53 & 0.001 & Accepted \\
H12 & ATT $\rightarrow$ WOM & 0.71 & 0.001 & Accepted \\
H13 & ATT $\rightarrow$ INP & 0.36 & 0.001 & Accepted \\
H14 & ATT $\rightarrow$ PIN & 0.58 & 0.001 & Accepted \\
H15 & PIN $\rightarrow$ WOM & 0.62 & 0.001 & Accepted \\
H16 & PIN $\rightarrow$ INP & 0.53 & 0.001 & Accepted \\
H17 & PIN $\rightarrow$ REL $\rightarrow$ INP & 0.08 & 0.19 & Rejected \\
H18 & ATT $\rightarrow$ REL $\rightarrow$ INP & 0.02 & 0.04 & Accepted \\
H19 & TRU $\rightarrow$ REL $\rightarrow$ INP & 0.21 & 0.001 & Accepted \\
\hline
\end{tabular}

Note:

- $\mathbf{R L D}=$ Perceived relative advantages; $\mathbf{C O P}=$ Compatibility; EOU $=$ Perceived ease of use; $\mathbf{U S F}=$ Perceived usefulness; TRU = Trust; $\mathbf{A T T}=$ attitude; $\mathbf{P I N}=$ Participation intention; WOM = Word of mouth; INP = Intention to purchase; $\mathbf{R E L}=$ Religiosity.

perceived ease of use on attitude $(\beta=0.27, \mathrm{p}<0.001)$. Similarly, for H6, the expected positive impact of perceived ease of use on perceived usefulness $(\beta=0.56, \mathrm{p}<0.001)$. Therefore, the results support H6.

With regard to $\mathrm{H} 7$ and $\mathrm{H} 8$, perceived usefulness is positively related to attitude $(\beta=0.32, \mathrm{p}<0.001)$ and consumer trust ( $\beta=0.67, \mathrm{p}<0.001)$. Therefore, the findings support $\mathrm{H} 7$ and $\mathrm{H} 8$.

Hypotheses 9, 10 and 11 concerned the influence of consumer trust in online travel community on attitude, intention to purchase and positive WOM. Our findings support the favourable effect of trust on attitude $(\beta=0.61, \mathrm{p}<0.001)$, intention to purchase travel online $(\beta=0.29, \mathrm{p}<0.001)$ and positive $\operatorname{WOM}(\beta=0.53, \mathrm{p}<0.001)$. Therefore, our findings support $\mathrm{H} 9, \mathrm{H} 10$, and $\mathrm{H} 11$.

With regard to $\mathrm{H} 12, \mathrm{H} 13$ and $\mathrm{H} 14$, attitude is positively related to positive WOM $(\beta=0.71, \mathrm{p}<0.001)$, intention to purchase travel online $(\beta=0.36, \mathrm{p}<0.001)$, and intention to participate $(\beta=0.58$, $\mathrm{p}<0.001)$. Therefore, the findings support H12, H13 and H14.

Hypotheses 15 and 16, that expected a positive relationship between intention to participate in online travel community and positive WOM $(\beta=0.62, \mathrm{p}<0.001)$ and intention to purchase travel online $(\beta=0.53, \mathrm{p}<0.001)$ were confirmed. Therefore, our results support $\mathrm{H} 15$ and $\mathrm{H} 16$.

In relation to the moderating role of religiosity, Hypotheses 17 , 18 and 19 concerned the moderating effects of religiosity on the relationship between intention to participate, attitude, trust, and intention to purchase travel online. The latter hypotheses were supported $(\beta=0.02, \mathrm{p}<0.05)$ and $(\beta=0.21, \mathrm{p}<0.001)$, while the former was not $(\beta=0.08, \mathrm{p}=0.19)$.

\subsection{Rival model}

There is a consensus in using structural equations modelling technique is that researchers should compare rival models, not just test a proposed research model (Kenneth \& Scott Long, 1992). Based 
on Morgan and Hunt (1994) and (Hair et al., 2010), we suggest a rival model as demonstrated in Fig. 3, where perceived usefulness, trust, attitude, and intention to participate do not act as mediators among the perceived relative advantages, compatibility, perceived ease of use and positive WOM and intention to purchase but they act as antecedents along with the perceived relative advantages, compatibility, and perceived ease of use.

The rival model has been evaluated on the basis of the following criteria: (1) overall fit of the model; and (2) percentage of the models' hypothesized parameters that are statistically significant (Hair et al., 2010; Morgan \& Hunt, 1994). The global fit indicators are as follow: $\mathrm{APC}=(0.491)$, ARS $=(0.518)$, AARS $=(0.503)$, AVIF $=(4.651)$, and GOF $=(0.536)$. All the goodness of fit measures fall below acceptable levels. Only five out of fourteen (36\%) of its hypothesized paths are supported at the $(\mathrm{p}<.01)$ level (including three out of fourteen $(22 \%)$ supported at $(\mathrm{p}<.001)$. In contrast, seventeen out of nineteen hypothesized paths (89\%) in the proposed model are supported at the $(\mathrm{p}<.001)$ level.

\subsection{Testing for mediation}

To check the mediating influence of the variables on intention to purchase travel online and positive WOM through relative advantages, compatibility, perceived ease of use, perceived usefulness, trust, attitude, and intention to participate, four separate analyses were performed using Baron and Kenny's (1986) approach. The results revealed that all standardized, indirect (i.e. mediated by relative advantages, compatibility and perceived ease of use) effects on intention to purchase and positive WOM are significant (please see Table 5). The full mediation model was supported. These findings are consistent with the path analysis results. We also conducted a Sobel test. The results also supported the mediating effects of perceived usefulness $(\mathrm{p}<0.001)$, trust $(\mathrm{p}<0.001)$, attitude $(\mathrm{p}<0.001)$, and intention to participate $(\mathrm{p}<0.001)$.

\section{Discussion and conclusions}

\subsection{Discussion of findings}

The aim of this study was to propose and empirically tests a
Table 5

Mediation analysis results.

\begin{tabular}{|c|c|c|c|c|c|c|}
\hline \multicolumn{2}{|l|}{ Fit estimates } & APC & ARS & AARS & AVIF & GOF \\
\hline \multicolumn{2}{|c|}{ Model 1, full mediation } & 0.174 & 0.782 & 0.749 & 2.841 & 0.694 \\
\hline \multicolumn{2}{|c|}{ Model 2} & 0.219 & 0.702 & 0.675 & 2.984 & 0.627 \\
\hline \multicolumn{2}{|c|}{ Model 3, no mediation } & 0.491 & 0.518 & 0.503 & 4.651 & 0.536 \\
\hline \multicolumn{2}{|c|}{ Model 4, partial mediation } & 0.192 & 0.742 & 0.694 & 2.964 & 0.614 \\
\hline & $\begin{array}{l}\text { Model 1, full } \\
\text { mediation }\end{array}$ & $\begin{array}{l}\text { Model } \\
2\end{array}$ & \multicolumn{2}{|c|}{$\begin{array}{l}\text { Model 3, no } \\
\text { mediation }\end{array}$} & \multicolumn{2}{|c|}{$\begin{array}{l}\text { Model } 4 \text {, partial } \\
\text { mediation }\end{array}$} \\
\hline \multicolumn{7}{|l|}{$\mathrm{R}^{2}$} \\
\hline Trust & 0.71 & - & 0.32 & & \multicolumn{2}{|l|}{0.71} \\
\hline Attitude & 0.53 & - & 0.29 & & \multicolumn{2}{|l|}{0.53} \\
\hline $\begin{array}{l}\text { Participate } \\
\text { intention }\end{array}$ & 0.74 & - & 0.41 & & \multicolumn{2}{|l|}{0.74} \\
\hline $\begin{array}{l}\text { Intention to } \\
\text { purchase }\end{array}$ & 0.78 & 0.19 & 0.53 & & \multicolumn{2}{|l|}{0.78} \\
\hline Positive WOM & 0.67 & 0.23 & 0.33 & & \multicolumn{2}{|l|}{0.67} \\
\hline
\end{tabular}

comprehensive model to identify key factors that affect the intention of consumer to participate in online travel community. We proposed a model in which perceived relative advantages, compatibility, perceived ease of use, perceived usefulness, trust and attitude act as antecedents to consumer intention to participate in online travel community. While, perceived usefulness, trust, attitude and intention to participate mediate the relationship between perceived relative advantages, compatibility, and perceived ease of use and intention to purchase travel online and positive WOM. Findings from online travel community members $(n=495)$ indicated that relative advantages, compatibility, perceived ease of use, perceived usefulness, trust, and attitude are key factors that affect the intention of consumer to participate in online travel community.

In this respect, consumers perceptions of relative advantages and compatibility seems to be key determinants of consumers intention to participate in online travel community, which is consistent with previous results found in the innovation diffusion theory (e.g., Agag \& El-Masry, 2016; Amaro \& Duarte, 2015; Lu et al., 2011; Rogers, 1995). However, contrary to what was expected on hypothesis one that relative advantages have a direct influence on consumer intention to participate in online travel community was not supported. Following the recommendations by Holmbeck

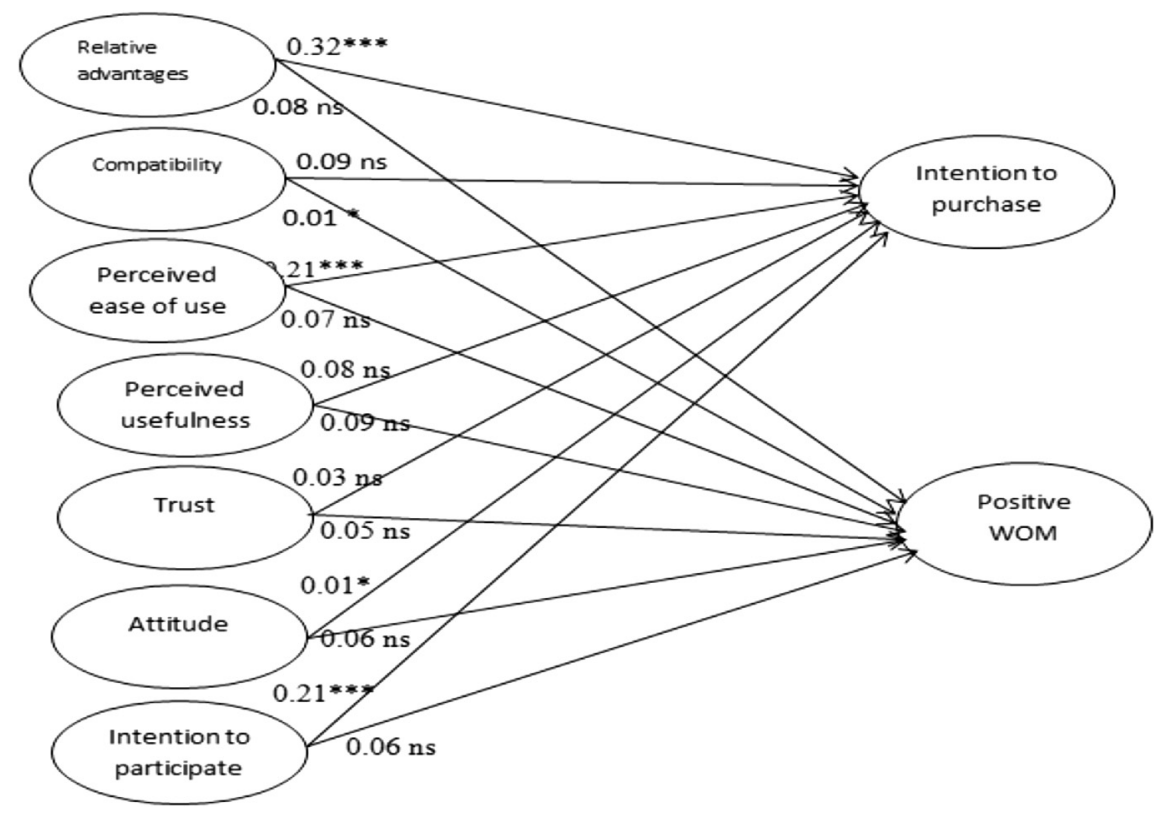

Fig. 3. A rival model. 
(1997) and Sobel's (1982) Z statistic showed that consumer attitude totally mediated the link between relative advantages and intentions to participate in online travel community. These results are in line with Amaro and Duarte (2015) findings in tourism context. Therefore, the relationship between relative advantages and intention to participate in online travel community must be analysed with caution.

The results indicate that perceived relative advantages and compatibility are related to consumer attitude toward online travel community, which in turn is significant predictor of consumer intention to participate in online travel community, which is in line with previous studies e.g., (Amaro \& Duarte, 2015; Jensen, 2009). Therefore, consumers who perceive the relative advantages of online travel community are more likely to have a positive attitude toward online travel community. At the same time, trust in online travel community, perceived ease of use, and perceived usefulness are three relevant antecedents in order to form a positive attitude toward online travel community and the intention to participate in online travel community. The main reason behind this maybe members prefer relying on personal communication and informal such as relying on other members on making purchase decisions rather than firms or formal sources (e.g., advertising campaigns) (Bansal \& Voyer, 2000; Casaló et al., 2011).

As well, the intention of consumers to participate favours the development of consumers' behavioural intentions to purchase travel online and enhances consumer intentions to recommend the online travel community and purchase its products. Therefore, travel firms have a good chance in order to increase their market share by developing positive recommendations between consumers (Casaló et al., 2011; Chung \& Darke, 2006). Finally, the study findings provided evidence for the moderating effect of religiosity on the relationship between consumer trust and attitude and intention to purchase travel online. Therefore, religiosity plays an important role in consumer attitude and behavioural intention.

\subsection{Managerial implications}

This study was couched on the premise that prior studies have largely ignored the factors leading to consumers' intention to participate in online travel community, especially in a developing country. As such, a strong empirical inquiry on analysing the determinants of consumers' intention to participate in online travel community as identified by the literature was needed. The present study's findings have revealed some important implications for online travel providers and academic researchers as well as making a significant contribution to the body of knowledge in a number of different ways.

The results of this research have relevant practical implications for marketing practitioners and managers who design strategic plans and implement tools to improve the performance of online travel websites.

First, the knowledge of the antecedents of consumers intention to participate and their effects on intention to purchase travel online and positive word of mouth is useful for managers who should develop strategies and actions aimed at increasing the consumer intention to participate in online travel community and, consequently, the consumer intention to purchase travel online and spreading positive word of mouth toward this online community.

Second, Trust and attitude can play a critical role in improving consumer intention to participate. In order to successfully increase consumer participation in online travel community, online travel community managers need to build online trust therefore forming positive attitude toward online travel community. The results showed that online travel community managers can create confidence in online travel community by perceived ease of use and perceived usefulness. Therefore, perceived usability or ease of use is a crucial aspect of the business strategy.

Third, perceived usefulness no only depends on perceived ease of use, but also on choosing the appropriate communication policy. Consumer cannot know the perceived usefulness of online travel community until they participate on it. In order to boost the online community perceived usefulness by new or potential consumers, benefits derived from the current members of the community must be clearly transmitted, so online community managers should maximize the experience of the current members in order to motivate this positive WOM. Mangers also can maximize the access to the online community by offering free trail periods without any membership fees.

Fourth, this study confirms that perceived ease of use and perceived usefulness influence consumer trust and attitude toward online travel community, consequently, intentions to book online, actions can be taken by managers to increase perceived ease of use and perceived usefulness. Online travel providers can utilize the advances of technology to facilitate convenience in selling travel online. For instance, online travel providers can provide apps for mobile devices to participate and purchase online. Therefore, online travel providers must provide customers with effective ways to increase the perceived ease of use, usefulness, and enhance the willingness to purchase online (e.g. guarantees, and security approval symbol).

Fifth, our study indicated that online travel community manager should pay close attention to compatibility and perceived relative advantages because they strongly and positively impact consumers' behaviour intention to participate. Compatibility exerts the greatest influence on consumer behaviour intention to participate. Therefore, online travel community managers should carefully consider the compatibility issues in order to make sure that their offerings meet consumers' needs, values, and lifestyles. Perceived relative advantages are also critical determinant of consumer intention to participate. Online communities should consider using tactics in order to increase consumers' perceived relative advantages by providing consumers with benefits e.g. convenience, lower price, time saving and relations with people who share the same interests.

Finally, Tourism and hospitality firms as well as some other tourism institutions will have a better understanding of the important role of religiosity and its effects on consumer behaviour intention and word of mouth which then can be used in planning their own future marketing strategies and plans.

\subsection{Theoretical implications}

This study has made several theoretical implications in various ways: First, It is among the first to examine the antecedents of consumes participation in online travel community based on a holistic approach, integrating several theories and validates the integration of these theories in the context of online travel. It confirms perceived relative advantages, compatibility, perceived ease of use, perceived usefulness, trust, and attitude as determinants of consumers' participation in the online travel community as hypothesized in the innovation diffusion theory and TAM. The study shows that innovation diffusion theory can be used to explain consumer intention to participate in online travel community, since the perceived relative advantages and compatibility are valid predictors of consumer intention to participate which in turn predict consumer intention to purchase travel online and positive word of mouth toward the online travel community. The study also indicate that TAM can be used to explain 
consumer intention to participate in online travel community, since the dimensions of TAM (perceived ease of use and perceived usefulness) act as antecedents to consumer trust and attitude which in turn predict consumer intention to participate in online travel community. Our study also indicated that consumer intention to participate in online travel community favours consumer behaviour intention development that can benefit the online travel community by recommending this online travel community and reuse its products. Furthermore, this study also contributes to the theory of religious tourism by examining the moderating role of religiosity in the relationship between consumer intention to participate and intention to purchase travel online. Although the number of studies conducted to investigate religiosity in the context of tourism is limited, the findings of this study confirm and reinforce the importance of religiosity in understanding consumer behaviour intention in the online travel context.

\subsection{Limitations and future research directions}

Like any other study, ours is bound by some limitations that also provide fertile grounds for further research. First, this study did not consider cross-cultural issues, any comparative study from a developed and developing country would make a worthwhile contribution to the body of knowledge. Second, despite the antecedents of consumer intention to participate in online travel community explained a substantial amount of its variance; there are some other important factors which have not been included in the research model, representing opportunities for further research (e.g. identification, perceived behavioural control, and subjective norms). Another future line of research is applying our proposed model to other online communities that would enable us to verify the generalizability to other populations and will contribute to the knowledge base on consumer participation. Our study does not consider the respondents economic status such as affordability. Previous studies found that affordability has a deep influence in determining the use of consumer of travel products and services. It should be noted that our target respondents are the potential consumers not the actual members of online travel community so we suppose that the potential consumers afford it. The online travel literature identifies some factors which influence consumer behaviour intention toward the online community (e.g., sex, age, income, and education). Such research could identify how each variable, individually and cooperatively, impacts consumer intention to participate. Finally, we did not collect data from nonInternet users because the focus of this study was online consumers. It may be an interesting extension, however, to test this conceptual model for other populations like non online consumers.

\section{Appendix}

Table 6

Descriptive statistics and normality tests of the constructs in the model.

\begin{tabular}{|c|c|c|c|c|c|}
\hline Statistics & Mean & SD & $\begin{array}{l}\text { Corrected } \\
\text { item-total } \\
\text { correlation }\end{array}$ & Skewness & Kurtosis \\
\hline \multicolumn{6}{|l|}{ Perceived relative advantages (RLD) } \\
\hline His online travel community provides more discounts than regular online shopping (RLD1). & 3.6 & 0.793 & 0.631 & -0.682 & 0.731 \\
\hline This online travel community is more convenient thin regular online shopping (RLD2). & 3.8 & 0.715 & 0.757 & -0.649 & 0.486 \\
\hline This online travel community helps me to save my time by purchasing travel online (RLD3). & 3.8 & 0.804 & 0.708 & -0.519 & 0.751 \\
\hline This online travel community provides product variety when purchasing online (RLD4). & 4.1 & 0.674 & & & \\
\hline \multicolumn{6}{|l|}{ Compatibility (COP) } \\
\hline Using-this online travel community to purchase travel is compatible. With the way I like to shop (COP1). & 3.8 & 0.825 & 0.751 & -0.683 & 0.538 \\
\hline Using this online travel community to purchase travel online fits with my lifestyle (COP2). & 3.6 & 0.759 & 0.827 & -0.657 & -0.293 \\
\hline I think that using this online travel community fits well with the way I like to work. (COP3). & 4.1 & 0.620 & 0.731 & -0.852 & 0.683 \\
\hline \multicolumn{6}{|l|}{ Perceived ease of use (EOU) } \\
\hline This online travel community is simple to use, even when using it for the first time (EOU1). & 3.6 & 0.817 & 0.727 & -0.683 & 0.610 \\
\hline In this online travel community everything is easy to find (EOU2). & 3.8 & 0.726 & 0.637 & -0.581 & 0.478 \\
\hline It is east to move within this online travel community (EOU3). & 4.3 & 0.582 & 0.652 & -0.672 & 0.392 \\
\hline \multicolumn{6}{|l|}{ Perceived usefulness (USF) } \\
\hline Using this online community helps me to solve doubts when I plan a travel (USF) & 4.2 & 0.621 & 0.593 & -0.837 & 0.803 \\
\hline Using this online community helps me to organize travels in a more efficient way (USF). & 3.4 & 0.826 & 0.637 & -0.532 & 0.648 \\
\hline In general, this online community is useful to plan travels (USF). & 4.1 & 0.512 & 0.738 & -0.372 & 0.584 \\
\hline \multicolumn{6}{|l|}{ Trust (TRU) } \\
\hline This online travel community has imparity (TRU1). & 4.3 & 0.701 & 0.762 & -0.539 & 0.384 \\
\hline This online travel community is reliable (TRU2). & 3.8 & 0.821 & 0.819 & -0.674 & 0.816 \\
\hline This online travel community is trustworthy (TRU3) & 4.1 & 0.740 & 0.746 & -0.782 & \\
\hline I trust on the quality of this online travel community (TRU4). & 3.9 & 0.785 & 0.825 & -0.846 & -0.470 \\
\hline \multicolumn{6}{|l|}{ Attitude (ATT) } \\
\hline I think participating in this online travel community would be good for me (ATT1). & 4.4 & 0.783 & 0.819 & -0.683 & 0.649 \\
\hline I think participating in this online travel community would be beneficial for me (ATT2). & 3.7 & 0.718 & 0.738 & -0.819 & 0.501 \\
\hline \multicolumn{6}{|l|}{ Intention to participate (PIN) } \\
\hline I have the intention to take part in the online travel community's activities (PIN1). & 3.9 & 0.914 & 0.702 & -0.410 & 0.647 \\
\hline I intend to actively participate in this online travel community (PIN2). & 4.2 & 0.807 & 0.820 & -0.387 & -0.128 \\
\hline \multicolumn{6}{|l|}{ Positive word of mouth (WOM) } \\
\hline I am willing to recommend this online travel community -and its product/services to others (WOM1). & 4.2 & 0.614 & 0.616 & -0.836 & 0.641 \\
\hline I usually say positive things about this- online travel community to others (WOM2). & 3.6 & 0.856 & 0.572 & -0.569 & 0.803 \\
\hline I will tell my friends and relatives to use this online travel products/service (WOM3). & 4.2 & 0.617 & 0.732 & -0.831 & 0.637 \\
\hline \multicolumn{6}{|l|}{ Intentions to purchase: travel online (LYP) } \\
\hline I expect to purchase travel online offered by this online community in the near future (INP1). & 2.9 & 0.814 & 0.574 & -1.738 & 0.467 \\
\hline I have the intention to use the products and services of this online community in the future (INP2). & 3.4 & 0.806 & 0.748 & -0.904 & 0.398 \\
\hline If I needed travel products and services, I would likely use the ones offered by this online community & 3.8 & 0.769 & 0.823 & -0.646 & 0.749 \\
\hline
\end{tabular}




\begin{tabular}{|c|c|c|c|c|c|}
\hline Statistics & Mean & SD & $\begin{array}{l}\text { Corrected } \\
\text { item-total } \\
\text { correlation }\end{array}$ & Skewness & Kurtosis \\
\hline \multicolumn{6}{|l|}{ Religiosity (KEL) } \\
\hline It is important to me to spend periods of time in private religious thought or prayer (REL1). & 3.9 & 0.841 & 0.692 & -0.918 & 0.637 \\
\hline My religious beliefs lie behind my whole approach, to life (REL2). & 3.5 & 0.857 & 0.861 & -0.805 & 0.498 \\
\hline I spent time trying to grow in understanding of my religious beliefs (REL3). & 2.8 & 0.930 & 0.771 & -0.684 & 0.804 \\
\hline I make financial contributions to my religious organization (REL4). & 3.2 & 0.805 & 0.816 & -0.726 & 0.637 \\
\hline I go to religious service because it helps me to make friends (REL5). & 4.1 & 0.854 & 0.863 & -0.374 & 0.743 \\
\hline I enjoy participating in the activities of my religious organization (REL6). & 3.6 & 0.826 & 0.779 & -0.403 & 0.483 \\
\hline
\end{tabular}

\section{References}

Agag, G., \& El-Masry, A. (2016). Understanding the determinants of hotel booking intentions and moderating role of habit. International Journal of Hospitality Management, 54, 52-67.

Agarwal, R. (2000). Individual acceptance of information technologies. Educational Technology Research and Development, 40, 90-102.

Akman, I., \& Mishra, A. (2015). Sector diversity in green information technology practices: technology acceptance model perspective. Computers in Human Behaviour, 49, ,477-486.

Alam, S., Mohd, R., \& Hisham, B. (2011). Is religiosity an important determinant on Muslim consumer behavior in Malaysia? Journal of Islamic Marketing, 2(1), 83-96.

Algesheimer, R. Dholakia, U. M. \& Herrmann, A (2005). The social influence of brand communities: evidence from European car clubs. Journal of Marketing, $59(3), 19-34$

Allport, G. W., \& Ross, J. M. (1967). Personal religious orientation and prejudice Journal of Personality and Social Psychology, 5(4), 432-443.

Alsajjan, B., \& Dennis, C. (2010). Internet banking acceptance model: cross-market examination. Journal of Business Research, 63(9), 957-963.

Amaro, S., \& Duarte, P. (2015). An integrative model of consumers' intentions to purchase travel online. Tourism Management, 46, 64-79.

Andersen, P. H. (2005). Relationship marketing and brand involvement of professionals through web-enhanced brand communities: the case of coloplast. Industrial Marketing Management, 34, 39-51.

Ardichvili, A. (2008). Learning and knowledge sharing in virtual communities of practice: motivators, barriers, and enablers. Advances in Developing Human Resources, 10(4), 541-554.

Ardichvili, A., Page, V., \& Wentling, T. (2003). Motivation and barriers to participation in virtual knowledge-sharing communities of practice. Journal of Knowledge Management, 7(1), 64-77.

Ashraf, A. R., Thongpapanl, N. T., \& Auh, S. (2014). The application of the technology acceptance model under different cultural contexts: the case of online shopping adoption. Journal of International Marketing, 22(3), 68-93.

Ayeh, J. K. (2015). Travellers' acceptance of consumer-generated media: an integrated model of technology acceptance and source credibility theories. Computers in Human Behavior, 48, 173-180.

Ayeh, J. K., Au, N., \& Law, R. (2013). Predicting the intention to use consumer generatedmedia for travel planning. Tourism Management, 35, 132-143.

Babbie, E. (2004). The practice of social research. Thomson: Wadsworth.

Bagozzi, R. P., Davis, F. D., \& Warshaw, P. R. (1992). Development and test of a theory of technological learning and usage. Human Relations, 45(7), 660-686.

Bagozzi, R. P., \& Dholakia, U. M. (2002). Intentional social action in virtual communities. Journal of Interactive Marketing, 16, 2-21.

Bagozzi, R. P., \& Dholakia, U. M. (2006). Open source software user communities: study of participation in linux user groups. Management Science, 52(7), $1099-1115$.

Bagozzi, R., \& Yi, Y. (1988). On the evaluation of structural equation models. Journal of the Academy of Marketing Science, 16(1), 74-94.

Balasubramanian, S., \& Mahajan, V. (2001). The economic leverage of the virtua community. International Journal of Electron Commerce, 5, 103-138.

Bansal, H. S., \& Voyer, P. A. (2000). Word-of-mouth processes within a services purchase decision context. Journal of Service Research, 3(2), 166-177.

Bartlett, J., Kotrlik, J., \& Higgins, C. (2010). Organizational research: determining appropriate sample size in survey research. Information Technology, Learning, and Performance Journal, 19(1), 43-50.

Baron, R. M., \& Kenny, D. A. (1986). The moderator-mediator variable distinction in social psychological research: conceptual, strategic, and statistical considerations. Journal of Personality and Social Psychology, 51, 1173-1182.

Bart, Y., Shankar, V., Sultan, F., \& Urban, G. L. (2005). Are the drivers and role of online trust the same for all web sites and consumers? A large-scale exploratory empirical study. Journal of Marketing, 69(4), 133-152.

Bellman, S., Lohse, G. L., \& Johnson, E. J. (1999). Predictors of online buying behavior. Communications of the ACM, 42(12), 32-38.

Bigne, E., Sanz, S., Ruiz, C., \& Aldas, J. (2010). Why some internet users don't buy air In U. Gretzel, R. Law, \& M. Fuchs (Eds.), Information and communication technologies in tourism (pp. 209-221).

Bock, G. W., \& Kim, Y.-G. (2002). Breaking the myths of rewards: an exploratory study of attitudes about knowledge sharing. Information Resources Management
Journal, 15(2), 14-21.

Buhalis, D. \& Law, R (2008). Progress in information technology and tourism management: 20 years on and 10 years after the internet e the state ofeTourism research. Tourism Management, 29(4), 609-623.

Butler, B. S. (2001). Membership size, communication activity, and sustainability: a resource-based model of online social structures. Information Systems Research, 12(4), 346-362.

Casaló, L. V., Flavián, C., \& Guinaliu, M. (2010). Determinants of the intention to participate in firm-hosted online travel communities and effects on consumer behavioral intentions. Tourism Management, 31, 898-911.

Casaló, L. V., Flavián, C., \& Guinalíu, M. (2011). Understanding the intention to follow the advice obtained in an online travel community. Computers in Human Behavior, 27, 622-633.

Chen, L., Gillenson, M. L., \& Sherrell, D. L. (2002). Enticing online consumers: an extended technology acceptance perspective. Information \& Management, 39(8), 705-719.

Cheng, T. C. E., Lam, D. Y. C., \& Yeung, A. C. L. (2006). Adoption of internet banking: an empirical study in Hong Kong. Decision Support Systems, 42(3), 1558-1572.

Chin, W. W. (2010). How to write up and report PLS analyses. In V. E. Vinzi, W. W. Chin, J. Henseler, \& H. Wang (Eds.), Handbook of partial least squares.

Chiu, C., Hsu, M., \& Wang, E. (2006). Understanding knowledge sharing in virtual communities: an integration of social capital and social cognitive theories. Decision Support Systems, 42(3), 1872-1888.

Chiu, C. M., Huang, H. Y., \& Hui, Y. C. (2010). Antecedents of trust in online auctions. Electronic Commerce Research and Applications, 9(2), 148-159.

Choi, B., \& Choi, B. J. (2014). The effects of perceived service recovery justice on customer affection, loyalty, and word-of-mouth. European Journal of Marketing, 48(1/2), 108-131.

Chung, C. M. Y., \& Darke, P. R. (2006). The consumer as advocate: self-relevance, culture and word-of-mouth. Marketing Letters, 17, 269-279.

Cleveland, M., Laroche, M., \& Hallab, H. (2013). Globalization, culture, religion, and values: comparing consumption patterns of Lebanese Muslims and Christians. Journal of Business Research, 66(8), 958-967.

Corritore, C. L., Kracher, B., \& Wiedenbeck, S. (2003). On-line trust: concepts, evolving themes, a model. International Journal of Human-Computer Studies, 58(6), 737-758.

Coulter, K. \& Coulter, R. (2002). Determinants of trust in a service provider: the moderating role of length of relationship. Journal of Services Marketing, 16(1), $35-50$.

Davis, F. D. (1986). A technology acceptance model for empirically testing new enduser information systems: Theory and results. Doctoral dissertation. Amherst, MA: Sloan School of Management Massachusetts Institute of Technology.

Davis, F. D. (1989). Perceived usefulness, perceived ease of use and user acceptance of information technology. MIS Ouarterly, 13(3), 319-340.

Davis, F. D., Bagozzi, R. P., \& Warshaw, P. R. (1989). User acceptance of computer technology: a comparison of two theoretical models. Management Science, 35(8), 982-1003.

Din, K. (1989). Islam and tourism: patterns, issues, and options. Annual Tourism Research, 16(4), 542-563.

Doney, P., \& Cannon, J. (1997). An examination of the nature of trust in the buyerseller relationship. Journal of Marketing 61, 35-51.

Egresi, I., Kara, F., \& Bayram, B. (2012). Economic impact of religious tourism in Mardin, Turkey. Journal of Economics and Business Research, 2, 7-22.

Elbeltagi, I., \& Agag, G. (2016). E-retailing ethics and its impact on customer satisfaction and repurchase intention: a cultural and commitment-trust theory perspective. Internet Research, 26(1), 288-310.

Escobar-Rodríguez, T., \& Carvajal-Trujillo, E. (2014). Online purchasing tickets for low cost carriers an application of the unified theory of acceptance and use of technology (UTAUT) model. Tourism Management, 43(August), 70-88.

Faraj, S., \& Johnson, S. L. (2011). Network exchange patterns in online communities. Organization Science, 22(6), 1464-1480.

Flavián, C., Guinalíu, M., \& Gurrea, R. (2006). The role played by perceived usability, satisfaction and consumer trust on website loyalty. Information \& Management, 43(1), 1-14.

Fornell, C., \& Larcker, D. F. (1981). Evaluating structural equation models with unobservable variables and measurement error. Journal of Marketing Research, 18, 39-50.

Gefen, D., Karahanna, E., \& Straub, D. W. (2003). Trust and TAM in online shopping: an integrated model. MIS Quarterly, 27(1), 51-90. 
Guo, Z., \& Sheffield, J. (2008). A paradigmatic and methodological examination of knowledge management research: 2000 to 2004. Decision Support Systems, 44, 673-688.

Hair, J. F., Black, W. C., Babin, B. J., \& Anderson, R. (2010). Multivariate data analysis. Upper Saddle River: Pearson Prentice-Hall.

Hair, J. F., Ringle, C. M., Hult, G. T., \& Sars. (2013). A primer on partial least squares structural equation modeling (PLS-SEM). Thousand Oaks, CA: SAGE Publications.

Ham, S., Kim, W. G., \& Forsythe, H. W. (2008). Restaurant employees' technology use intention: Validating technology acceptance model with external factors. Journal of Hospitality \& Leisure Marketing, 17(1/2), 78-98.

Harris, L. C., \& Goode, M. M. H. (2004). The four levels of loyalty and the pivotal role of trust: a study of online services dynamics. Journal of Retailing, 80, 139-158.

Henseler, J., Ringle, C. M., \& Sarstedt, M. (2012). Using partial least squares path modeling in international advertising research: basic concepts and recent issues. In S. Okazaki (Ed.), Handbook of research in international advertisin (pp. 252-276).

Holmbeck, G. N. (1997). Toward terminological, conceptual, and statistical clarity in the study of mediators and moderators: examples from the child-clinical and pediatric psychology literature. Journal of Consulting and Clinical Psychology, 65(4), 599-610.

Hsu, C. L., \& Lin, J. C. C. (2008). Acceptance of blog usage: the roles of technology acceptance, social influence and knowledge sharing motivation. Information Management, 45, 65-74.

Hsu, M. H., Yen, C. H., Chiu, C. M., \& Chang, C. M. (2006). A longitudinal investigation of continued online shopping behavior: an extension of the theory of planned behaviour. International Journal of Human-Computer Studies, 64, 889-904.

Hung, Y. C., Yang, Y. L., Yang, H. E., \& Chuang, Y. (2011). Factors affecting the adoption of e-commerce for the tourism industry in Taiwan. Asia Pacific Journal of Tourism Research, 16(1), 105-119.

Huysman, M., \& Wulf, V. (2005). IT to support knowledge sharing in communities, towards a social capital analysis. Journal of Information Technology, 21(1), 40-51.

Jan, A. U., \& Contreras, V. (2011). Technology acceptance model for the use of information technology in universities. Computers in Human Behavior, 27, $845-851$.

Jensen, J. M. (2009). Travellers' intentions to purchase travel products online: the role of shopping orientation. In A. Matias, P. Nijkamp, \& M. Sarmento (Eds.), Advances in tourism economics: New developments (pp. 203-215). Heidelberg, Germany: Physica.

Jonassen, D. H., Howland, J., Moore, J., \& Marra, R. M. (2003). Learning to solve problems with technology: A constructivist perspective (2nd ed.). Columbus, $\mathrm{OH}$ : Merrill/Prentice Hall.

Joo, J., \& Sang, Y. (2013). Exploring Koreans' smartphone usage: an integrated model of the technology acceptance model and uses and gratifications theory. Computers in Human Behavior, 29(6), 2512-2518.

Joseph, C., \& Kavoori, A. (2001). Mediated resistance: tourism and the host community. Annual Tourism Research, 28(4), 998-1009.

Kamarulzaman, Y. (2007). Adoption of travel e-shopping in the UK. International Journal of Retail \& Distribution Management, 35(9), 703-719.

Karahanna, E., Straub, D. W., \& Chervany, N. L. (1999). Information technology adoption across time: a cross-sectional comparison of pre-adoption and postadoption beliefs. MIS Quarterly, 23(2), 183-213.

Kenneth, B., \& Scott Long, J. (1992). Tests for structural equation models: introduction. Sociological Methods and Research, 21(November), 123-131.

Kim, M. J., Chung, N., \& Lee, C. K. (2011). The effect of perceived trust on electronic shopping online for tourism products and services in South Korea. Tourism Management, 32(2), 256-265.

Kim, D. J., Ferrin, D. L., \& Rao, H. R. (2008). A trust-based consumer decision-making model in electronic commerce: the role of trust, perceived risk, and their antecedents. Decision Support Systems, 44(2), 544-564.

Kim, H. B., Kim, T., \& Shin, S. W. (2009). Modeling roles of subjective norms and eTrust in customers' acceptance of airline B2C E-Commerce websites. Tourism Management, 30, 266-277.

Kim, T. G., Lee, J. H., \& Law, R. (2008). An empirical examination of the acceptance behaviour of hotel front office systems: an extended technology acceptance model. Tourism Management, 29(3), 500-513.

Kim, Xu, Y., \& Gupta, S. (2012). Which is more important in Internet shopping, perceived price or trust? Electronic Commerce Research and Applications, 11(3), 241-252.

Kirillovaa, K., Gilmetdinovab, A., \& Lehtoc, X. (2014). Interpretation of hospitality across religions. International Journal of Hospitality Management, 43, 23-34.

Koh, J., \& Kim, D. (2004). Knowledge sharing in virtual communities: an e-business perspective. Expert Systems with Application, 26, 155-166.

Koufaris, M., \& Hampton-Sosa, W. (2004). The development of initial trust in an online company by new customers. Information \& Management, 41(3), 377-397.

Lai, I. K. W., Hsu, C. C. F., \& Chung, W. W. C. (2010). Preliminary study of green manufacturing technology acceptance in China. In Proceedings of 8th International Conference on Supply Chain Management and Information Systems (SCMIS), 6-9 Oct. 2010, Hong Kong, 1-7.

Law, R., \& Wong, J. (2003). Successful factors for a travel website: perceptions of online purchasers in Hong Kong. Journal of Hospitality \& Tourism Research, 27(1), 118-124.

Lee, Y. H., Hsieh, Y. C., \& Hsu, C. N. (2011). Adding innovation diffusion theory to the technology acceptance model: supporting employees' intentions to use elearning systems. Educational Technology \& Society, 14(4), 124-137.

Li, L., \& Buhalis, D. (2006). E-commerce in China: the case of travel. International
Journal of Information Management, 26(2), 153-166.

Lien, C. H., \& Cao, Y. (2014). Examining We Chat users' motivations, trust, attitudes, and positive word-of-mouth: evidence from China. Computers in Human Behavior, 41,104-41,111.

Limayem, M., Khalifa, M., \& Frini, A. (2000). What makes consumers buy from internet? A longitudinal study of online shopping. IEEE Transactions on Systems, Man, and Cybernetics e Part A. Systems and Humans, 30(4), 421-432.

Lim, K. S., Lim, J. S., \& Heinrichs, J. H. (2008). Testing an integrated model of eshopping web site usage. Journal of Internet Commerce, 7(3), 291-312.

Llach, J., Mariomon, F., \& Alonso-Almeida, M. (2013). Determinants of online booking loyalties for the purchasing of airline tickets. Tourism Management, 35(April), 23-31.

Lu, Y., Yang, S., Chau, P. Y., \& Cao, Y. (2011). Dynamics between the trust transfer process and intention to use mobile payment services: a cross-environment perspective. Information \& Management, 48, 393-403.

McKnight, D. H., Choudhury, V., \& Kacmar, C. (2002). The impact of initial consume trust on intentions to transact with a web site: a trust building model. Journal of Strategic Information Systems, 11, 297-323.

Millen, D. R., Fontaine, M. A., \& Muller, M. J. (2002). Understanding the benefit and costs of communities of practice. Communications of the ACM, 45, 69-73.

Mohammadi, H. (2015). Investigating users' perspectives on e-learning: an integration of TAM and IS success model. Computers in Human Behavior, 45(1), 359-374.

Moital, M., Vaughan, R., Edwards, J., \& Peres, R. (2009). Determinants of intention topurchase over the internet. An International Journal of Tourism and Hospitality Research, 20(2), 345-358.

Morgan, R. M., \& Hunt, S. D. (1994). The commitment-trust theory of relationship marketing. Journal of Marketing, 58(3), 20-38.

Morosan, C. (2012). Theoretical and empirical considerations of guests' perceptions of biometric systems in hotels: extending the technology acceptance model. Journal of Hospitality \& Tourism Research, 36(1), 52-84.

Morosan, C., \& Jeong, M. (2008). Users' perceptions of two types of hotel reservation web sites. International Journal of Hospitality Management, 27(2), 284-292.

Muñiz, A., \& Schau, H. J. (2005). Religiosity in the abandoned Apple Newton brand community. Journal of Consumer Research, 31, 737-747.

Nunnally, J., \& Bernstein, I. H. (1994). Psychometric theory (3rd ed.). London: McGraw Hill.

Palvia, P. (2009). The role of trust in e-commerce relational exchange: a unified model. Information and Management, 46(4), 213-220.

Park, A., \& Yang, B. (2012). Online environmental community members' intention to participate in environmental activities: an application of the theory of planned behaviour in the Chinese context. Computers in Human Behaviour, 28 1298-1306.

Persico, D., Manca, S., \& Pozzi, F. (2014). Adapting the technology acceptance model to evaluate the innovative potential of e-learning systems. Computers in Human Behavior, 30, 614-622.

Ponte, E. B., Carvajal-Trujill, E., \& Escobar-Rodr, T. (2015). Influence of trust and perceived value on the intention to purchase travel online: integrating the ef fects of assurance on trust antecedents. Tourism Management, 47, 286-302.

Prahalad, C. K. (2000). Ramaswamy, Co-opting customer competence. Harvard Business Review, 78, 79-87.

Procaci, T. B., Siqueira, S. W. M., Braz, M. H. L. B., \& Andrade, L. C. V. (2015). How to find people who can help to answer a question? - Analyses of metrics and machine learning in online communities. Computers in Human Behavior, 51, 664-673.

Qu, H., \& Lee, H. (2011). Travelers' social identification and membership behaviors in online travel community. Tourism Management, 32(6), 1262-1270.

Raban, D. R., Moldovan, M., \& Jones, Q. (2010). An empirical study of critical mass and online community survival. In Proceedings of the 2010 ACM conference on Computer supported cooperative work - CSCW, 10 pp. 71-80).

Ranganathan, S., \& Henley, W. (2007). Determinants of charitable donation intentions: a structural equation model. International Journal of Nonprofit and Voluntary Sector Marketing, 13(1), 1-11.

Ridings, C. M., Gefen, D., \& Arinze, B. (2002). Some antecedents and effects of trust in virtual communities. Journal of Strategic Information Systems, 11, 271-295.

Rogers, E. M. (1995). Diffusion of innovations (4th ed.). New York: Free Press.

San Martín, H., \& Herrero, A. (2012). Influence of the user's psychological factor son the online purchase intention in rural tourism: integrating innovativeness to the UTAUTframework. Tourism Management, 33(2), 341-350.

Sanz-Blas, S., Ruiz-Mafe, C., \& Perez, P. (2014). Key drivers of services website loyalty. The Service Industries Journal, 34(5), 455-475.

Schlosser, A. E., White, T. B., \& Lloyd, S. M. (2006). Converting web site visitors into buyers: how web site investment increases consumer trusting beliefs and online purchase intentions. Journal of Marketing, 70(April), 133-148.

Shih, H. P., Lai, K. H., \& Cheng, T. C. E. (2013). Informational and relational influences on electronic word of mouth: an empirical study of an online consumer discussion forum. International Journal of Electronic Commerce, 17(4), 137-165.

Sia, L. C., Lim, K. H., Leung, K., Lee, M. K. O., \& Huang, W. W. (2009). Web strategies to promote internet shopping: is cultural-customization needed? MIS Quarterly, 33(3), 491-512.

Sobel, M. E. (1982). Asymptotic confidence intervals for indirect effects in structural equation models. Sociological Methodology, 13(1), 290-312.

Swimberghe, K., Flurry, L. A., \& Parker, J. M. (2011). Consumer religiosity: consequences for consumer activism in the United States. Journal of Business Ethics, $103,453-467$. 
Terzidou, M., Stylidis, D., \& Szivas, E. (2008). Residents' perceptions of religious tourism and its socio-economic impacts on the island of Tinos. Tourism and Hospitality Planning \& Development Journal, 5(2), 113-129.

Tiwana, A., \& Bush, A. A. (2005). Continuance in expertise-sharing networks : a social perspective. IEEE Transactions on Engineering Management, 52(1), 85-101.

Toral, S. L., Martínez-Torres, M. R., \& Barrero, F. (2010). Analysis of virtual communities supporting OSS projects using social network analysis. Information and Software Technology, 52(3), 296-303.

Tsai, H. T., \& Pai, P. (2014). Why do newcomers participate in virtual communities? An integration of self-determination and relationship management theories. Decision Support Systems, 57, 178-187.

Urbach, N., \& Ahlemann, F. (2010). Structural equation modeling in information systems research using partial least squares. Journal of Information Technology Theory and Application, 11, 5-40.

Venkatesh, V. (2000). Determinants of perceived ease of use: integrating control intrinsic motivation, and emotion into the technology acceptance model. Information Systems, 1997, 342-365.

Venkatesh, V., \& Davis, F. D. (2000). A theoretical extension of the technology acceptance model: four longitudinal field studies. Management Science, 46(2), $186-204$.

Vijayasarathy, L. R. (2004). Predicting consumer intentions to use on-line shopping: the case for an augmented technology acceptance model. Information \& Management, 41(6), 747-762.

Wang, X. (2007). An ecological perspective on online communities. Ph.D. Dissertation. University of Pittsburgh.

Wang, X., Butler, B., \& Ren, Y. (2011). The impact of membership overlap on growth: an ecological competition view of online groups. Articles in Advance, 1-36.
Wang, Y., \& Fesenmaier, D. R. (2004). Towards understanding members' general participation in and active contribution to an online travel community. Tourism Management, 25, 709-722.

Wang, Y., Yu, Q., \& Fesenmaier, D. R. (2002). Defining the virtual tourist community: implications for tourism marketing. Tourism Management, 23, 407-417.

Wasko, M. M., \& Faraj, S. (2005). Why should I share? Examining social capital and knowledge contribution in electronic networks of practice. MIS Quarterly, 29, 35-57.

Wen, I. (2010). Online travelers' decision makings: a new equation model to evaluate impacts of website, search intention, and trust. Information Technology \& Tourism, 12(2), 153-173.

Wenger, E. (1998). Communities of practice: Learning, meaning, and identity. Cambridge: Cambridge University Press.

Wiertz, C., \& Ruyter, K. D. (2007). Beyond the call of duty: why customers contribute to firm-hosted commercial online communities. Organization Studies, 28 347-376.

Workman, M. (2014). New media and the changing face of information technology use: the importance of task pursuit, social influence, and experience. Computers in Human Behavior, 111-117, 31.

Yang, H. D., \& Yoo, Y. (2004). It's all about attitude: revisiting the technology acceptance model. Decision Support System, 38(1), 19-31.

Yu, T. K., \& Wu, G. S. (2007). Determinants of internet shopping behavior: an application of reasoned behaviour theory. International Journal of Management, 24(4), 744-762.

Zhu, D. H., \& Chan, Y. P. (2014). Investigating consumer attitude and intention toward free trials of technology-based services. Computers in Human Behavior, 30, $328-334$. 